\title{
Article \\ Health Risk Assessment for the Residential Area Adjacent to a Former Chemical Plant
}

\author{
Eleonora Wcisło * (D) and Joachim Bronder
}

check for updates

Citation: Wcisło, E.; Bronder, J. Health Risk Assessment for the Residential Area Adjacent to a Former Chemical Plant. Int. J. Environ. Res. Public Health 2022, 19, 2590. https://doi.org/10.3390/ ijerph19052590

Academic Editor: Paul B. Tchounwou

Received: 14 December 2021

Accepted: 14 February 2022

Published: 23 February 2022

Publisher's Note: MDPI stays neutral with regard to jurisdictional claims in published maps and institutional affiliations.

Copyright: (C) 2022 by the authors. Licensee MDPI, Basel, Switzerland. This article is an open access article distributed under the terms and conditions of the Creative Commons Attribution (CC BY) license (https:// creativecommons.org/licenses/by/ $4.0 /)$.
Institute for Ecology of Industrial Areas, 6 Kossutha St., 40-844 Katowice, Poland; j.bronder@ietu.pl

* Correspondence: e.wcislo@ietu.pl; Tel.: +48-3225-46031
Abstract: A health risk assessment was carried out for the residents of Łegnowo-Wieś settlement adjacent to a former Zachem Chemical Plant, Bydgoszcz, Poland. Due to the unique Zachem site history and contamination profile, an innovative strategy for soil sampling and contaminant selection was applied. The novelty in the developed strategy consisted of selecting substances for the health risk assessment, taking into consideration the location and boundaries of the groundwater contamination plumes in relation to contamination sources. This allowed limiting the number of the analysed contaminants. The risk assessment focused on the surface soil of a residential area, which was divided into 20 sampling sectors and 6 backyards with wells from which water was used for watering edible plants. A total of 80 inorganic and organic substances were determined, including metals, phenol, aniline, BTEX, diphenyl sulphone, chloroaniline, epichlorohydrin, hydroxybiphenyl, nitrobenzene, octylphenols, toluenediamine, toluidine, 16 polycyclic aromatic hydrocarbons, tetrachloroethylene and trichloroethylene. For the health risk assessment, the United States Environmental Protection Agency's deterministic method was applied. This applies conservative assumptions to obtain risk estimates protective for most of the potential receptors. Three exposure pathways were analysed: (1) incidental soil ingestion, (2) dermal contact with soil and (3) inhalation of fugitive soil particles and volatiles. In all sampling sectors and backyards, the total non-cancer risks (hazard index) were significantly lower than the acceptable level of 1 . The acceptable cancer risk level for the single carcinogen of $1 \times 10^{-5}$ was only insignificantly exceeded in the case of benzo(a)pyrene in three sectors and one backyard. The total cancer risks were lower than the acceptable level of $1 \times 10^{-4}$ in all sampling sectors and all backyards. The findings show that the soil in the entire residential area is safe for the residents' health and no remedial actions are required. However, since not all possible exposure pathways were analysed in this study, further research focused on assessing the health risk resulting from the consumption of locally grown food is strongly recommended.

Keywords: soil pollution; human health risk assessment; risk-based remedial levels; chemical plant; residential area

\section{Introduction}

There are millions of abandoned and still used contaminated sites around the world. It is estimated that only in the European Union (EU) there may be about 2.8 million contaminated sites, with more than 650,000 of them being registered in the national and regional inventories [1] (The problem of contaminated sites is particularly significant in the case of historical contamination and relates to abandoned sites. Such sites, if not remediated, may pose a health risk to current or future users and nearby residents, and, in particular, to the most sensitive groups, such as foetuses, children and pregnant women [2].

Soil contamination can be caused by various anthropogenic activities, such as industrial processes, mining, inappropriate waste management and treatment, agriculture, extraction and processing of fossil fuels or emissions from transport [2-4]. Soil contaminants can affect the air, surface and groundwater. They can also enter the food chain and cause diseases and mortality in living organisms, including humans [2,5-7]. The impact 
of soil contamination on human health has been studied for many years, particularly intensively in recent years. These studies have been conducted in areas of different anthropogenic activities, especially in urban and mining areas, in the vicinity of industrial areas, in the areas affected by warfare activities and agricultural areas [8-11]. In the assessment of the impact on human health, both inorganic and organic contaminants were taken into account. However, potentially toxic elements (arsenic and heavy metals) were assessed the most often [9,12-18]. Among organic compounds the studies often included polycyclic aromatic hydrocarbons (PAHs), [19-25], petroleum hydrocarbons [22,26,27] and pesticides [3,11,28,29].

In Europe, the problem of historically contaminated soil is caused by using dangerous substances in many production processes and the lack of legally imposed emission control or protective measures. This problem is visible especially in Eastern and Central Europe, including Poland [1].

The economic changes taking place in the nineties of the 20th century caused liquidation of industrial plants located in cities, which resulted in a number of abandoned, heavily contaminated sites. The complex environmental problems they cause and their scale allow calling these sites "megasites" or even "environmental bombs". In Poland alone there are several such sites, for example: Tarnowskie Góry Chemical Plant [30], Organika-Azot S.A. Chemical Plant in Jaworzno [31] and Zachem Chemical Plant in Bydgoszcz [32].

As for the abandoned Zachem Chemical Plant (CP), the area was partially remediated and re-used as a technological park. However, the impact of this site on the health of people who live in the vicinity of this plant has not been assessed, causing concern for them and their children.

The aim of the study was to assess the health risk posed to the residents of the Łegnowo-Wieś settlement (ŁWS) situated in the vicinity of the Zachem CP. It was intended to be achieved through:

- development of an innovative strategy for soil sampling and contaminant selection, taking into consideration the location and boundaries of the groundwater contamination plumes in relation to contamination sources;

- selecting substances for health risk assessment according to the developed strategy;

- $\quad$ soil sampling and chemical analyses;

- $\quad$ assessing the health risk to the residents of $€ W S$ as a result of the potential exposure to the selected contaminants;

- developing the site-specific health risk-based target levels (HRBTLs) for the selected contaminants.

\section{Materials and Methods}

\subsection{Site Area}

The former Zachem CP is located in the city of Bydgoszcz $\left(53^{\circ} 07^{\prime} 24^{\prime \prime} \mathrm{N} ; 18^{\circ} 00^{\prime} 27^{\prime \prime} \mathrm{E}\right)$, in the northern part of Poland. The site is situated in the south-eastern part of the city, at a distance of about $7 \mathrm{~km}$ from the city centre (Figure 1). Its area covers ca. 2000 ha.

The Zachem CP was established in the place of the former German explosives factory built during the Second World War [33]. The main products of the factory were: nitrocellulose, smokeless gunpowder and nitroglycerine, trinitrotoluene-TNT (trotyl), dinitrobenzene, V1 missiles, aircraft bombs, artillery shells and gunpowder fuses [34]. In 1948-1952, the plant produced mainly explosives, such as trotyl, penthrite and tetryl for military and civilian needs. Acid denitration and nitrating acid management were also conducted. Moreover, dyes, dyeing intermediates, pigments, phenol, optical brighteners, nitrobenzene, aniline and the products made from processed poly(vinyl chloride) (PVC) were produced. In the 70s, the production of flexible polyurethane (PU) foams and fittings from $\mathrm{PU}$ foams for the automotive industry was started and installations for the production of phosgene, dinitrotoluene (DNT), toluenediamine (TDA), toluene diisocyanate (TDI), epichlorohydrin (EPI) and electrolysis of brine were launched [33]. 


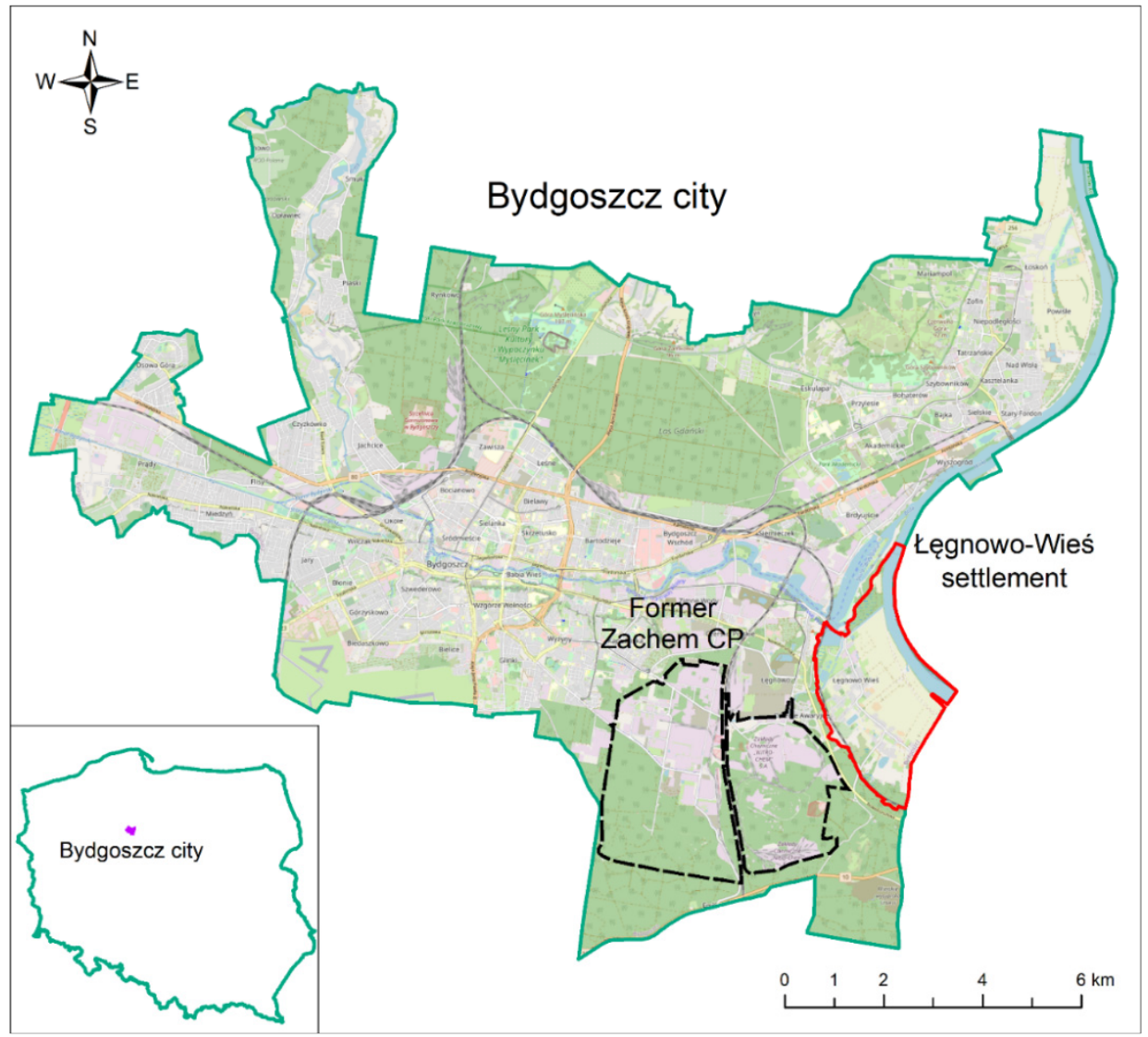

Figure 1. Location of the former Zachem Chemical Plant and the Eegnowo-Wieś settlement on the map of Bydgoszcz, Poland.

In 1981-1990, the basic production of the Zachem CP was continued, but later on there was no further development due to economic problems in Poland. In the 90s, the eco-restructuring of the production was undertaken, which resulted in the closure of the most harmful installations. Since that time the plant has been reorganised, modernised and its production profile has altered. In the first decade of the 2000s, the most important production profile included: products made from processed PVC, PU foams, EPI and TDI [33]. In 2012, the production of the plant ceased. In 2014, the company was declared bankrupt, and since then its assets have been managed by a trustee [35].

The Łegnowo-Wieś settlement (ŁWS) is located at the south-eastern side of the former Zachem CP (Figure 1). It covers the area of 736 ha and has ca. 1600 inhabitants. People live mainly in detached houses with backyards. In the eastern part of the settlement an agricultural area of 378.5 ha with a high groundwater level is located. Since 1963, residents of the $€ W S$ have reported the deterioration of water quality in private domestic wells. Zachem CP started providing drinking water to them from its own water intake [35]. Since 2014, drinking water has been provided for residents from the municipal water mains. However, some domestic wells are still used for watering edible plants grown in home gardens.

In the previous decade, detailed exploratory studies in the Zachem CP area were conducted, mainly by AGH University of Science and Technology, Cracow and the Bydgoszcz Regional Directorate for Environmental Protection (BRDEP), [36,37]. AGH and BRDEP delineated 17 and 19 main contamination sources in the Zachem CP area, respectively (Figure 2). The studies pointed out the following most dangerous contamination sources: Zielona landfill (tens of thousands of tons of post-phenol sodium sulphite accumulated on 11 ha area), Lisia landfill (sodium sulphite contaminated with phenol), the former EPI sediment pond, the aniline sludge storages, the nitrobenzene pocket area, the TDI/TDA contaminated area and DNT installation [37]. Findings of the same studies conducted in 
and outside the Zachem CP area showed that the contaminated groundwater flowed from the Zachem area towards north-east and eastwards to the Vistula River and northwards to the Brda River and impacted the nearby residential area (ŁWS). Moreover, five probable partially overlapping plumes of groundwater contamination were identified in association with pollution sources: plume 1-incineration site in Żółwino, where, additionally, waste from heat and power plant was stored (this groundwater contamination source was unexpectedly identified outside the $\mathrm{CP}$ ), plume 2-Zielona landfill complex, plume 3-nitrobenzene pocket or DNT installation, plume 4 and 5-central part of the former CP, including aniline sludge, Lisia landfill and EPI sediment pond [37].

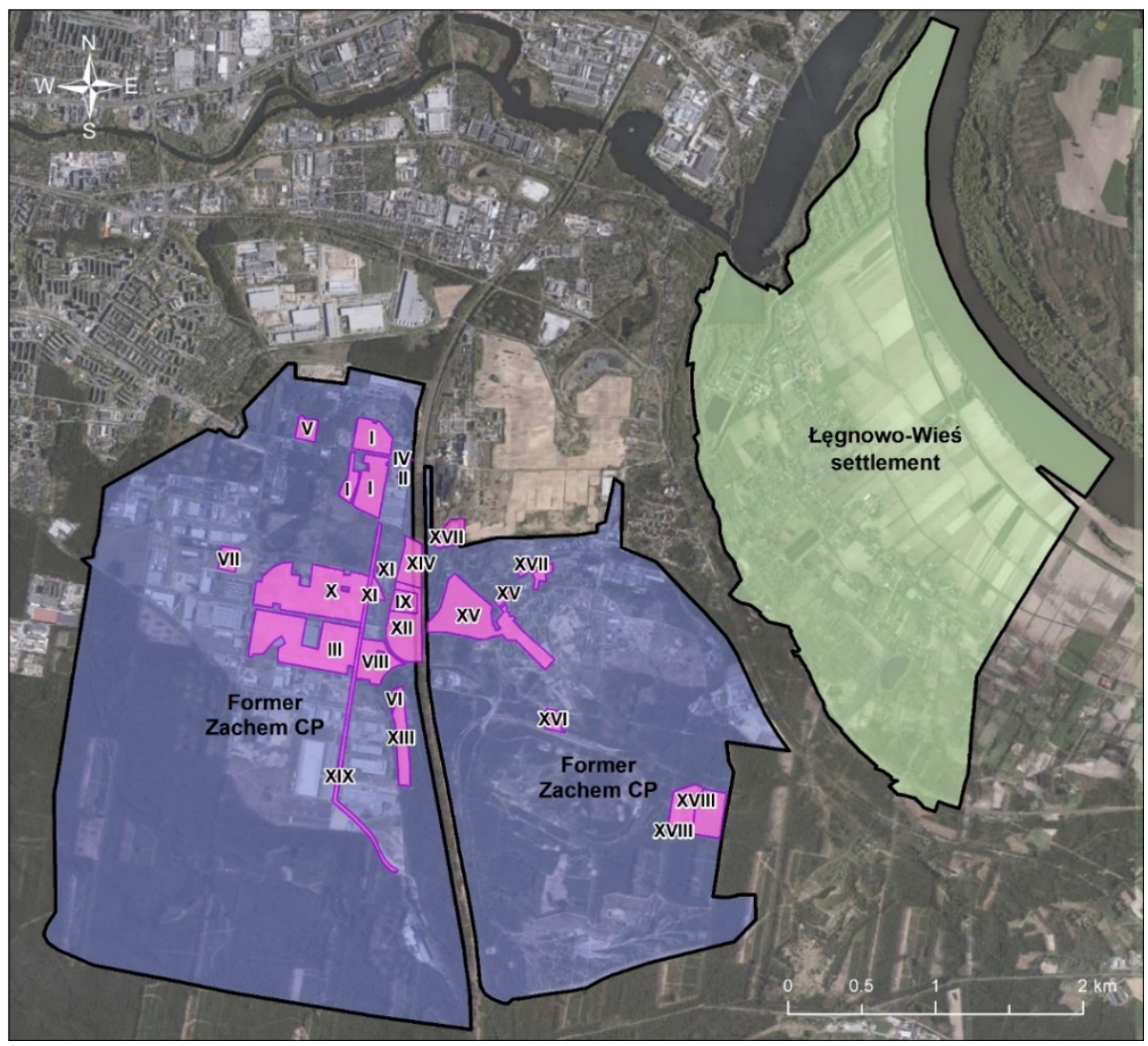

Figure 2. Location of the main contamination sources in the former Zachem CP area by BRDEP, based on Czop et al. [37]; I: dye plant, II: dye waste pit, III: monomer complex installation, IV: cold control unit, V: manufacturing of polyester polyols and polyurethane systems, VI: TDI tar extinguishing site (former electroplating waste landfill), VII: brine electrolysis area, brine reservoirs, VIII: propylene warehouse, IX: heat and power plant ash and slag landfill, X: TDI/TDA contaminated area, XI: EPI installation, XII: EPI sedimentary pond, XIII: Lisia landfill, XIV: central sewage neutralisation station, XV: three aniline sludge storages (pits), XVI: DNT installation, XVII: old boiler house, XVIII: Zielona landfill complex, XIX: brine pipeline route.

\subsection{Soil Sampling Approach and Selection of Contaminants}

The soil sampling plan for the ŁWS was developed in compliance with the Regulation of the Minister of the Environment dated 1 September 2016 on the method of conducting the assessment of land surface contamination [36], based on the findings of the previous investigations conducted in the Zachem CP area by the AGH University of Science and Technology [37,38] and Arcadis [39]. Apart from that, numerical cartographic data in the form of a land and building registry map and a map of the ŁWS borders were used for this purpose.

According to the Regulation [38], the number of soil sampling sectors was established based on land use patterns (residential, industrial and agricultural) and the site area. Minimal number of soil samples for residential area is presented in Table 1. 
Table 1. Minimal number of soil samples in sampling sectors for residential area [39].

\begin{tabular}{cccc}
\hline $\begin{array}{c}\text { Site Area } \\
\text { (ha) }\end{array}$ & $\begin{array}{c}\text { Sector Area } \\
\text { (ha) }\end{array}$ & $\begin{array}{c}\text { Number of Sectors } \\
\text { (Composite Samples) }\end{array}$ & $\begin{array}{c}\text { Number of Individual } \\
\text { Soil Samples }\end{array}$ \\
\hline$\leq 0.05$ & $\leq 0.05$ & 1 & 15 \\
$0.05-1$ & $(0.05 / 3)-0.1$ & $3-10$ & $45-150$ \\
$1-10$ & $0.1-0.5$ & $10-20$ & $150-300$ \\
$>10$ & $\leq 5$ & $\geq 20$ & $\geq 300$ \\
\hline
\end{tabular}

The $Ł W S$ covers an area of about 736 ha. Residential buildings are situated on 164 plots, which constitute a residential development area of 31.1 ha. This area was divided into 20 soil sampling sectors, taking into account the location of groundwater contamination plumes and topographic relief. Most of the soil sampling sectors (seven) were within the extent of the contamination plume 4 and only one within the extent of the plume 5; five sampling sectors were within the extent of contamination plumes 2 and 3, and two were within the plume 1. Figure 3 presents the location of the soil sampling sectors in the residential development area of ŁWS against the background of groundwater contamination plumes. According to the Regulation [39], a total of 20 composite soil samples were taken, i.e., one in each soil sampling sector. Each composite soil sample was made up of at least 15 individual samples taken from the surface soil layer of $0-0.25 \mathrm{~m}$. The composite soil samples were intended for measuring the content of substances in the surface layer as this is the soil layer people make contact with directly.

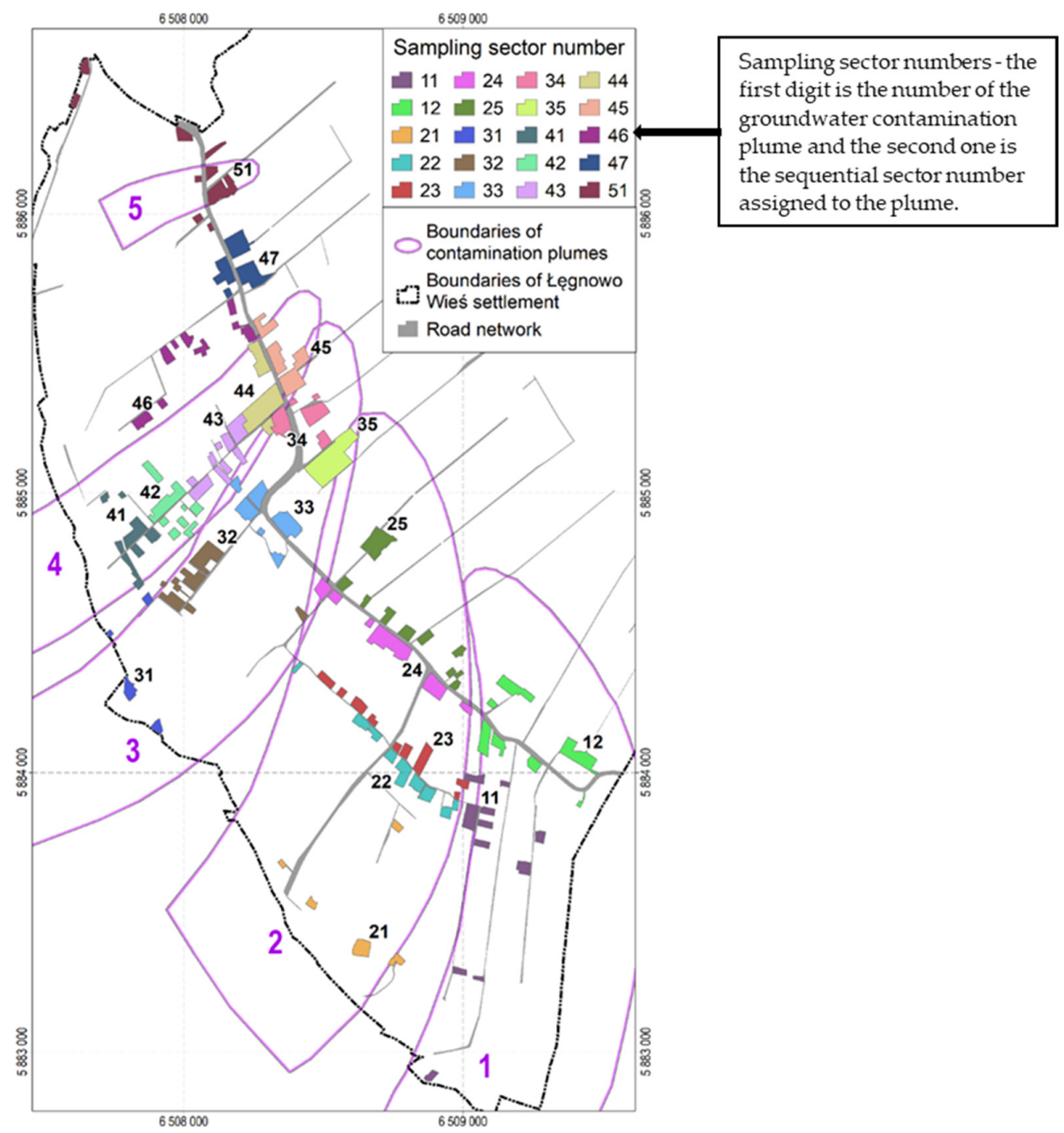

Figure 3. Location of soil sampling sectors in the residential development area of ŁWS against the background of groundwater contamination plumes (based on Czop et al. [37]. 
For identification of volatiles, it was necessary to collect samples from deeper soil layers. This was related to the possibility of penetration of substance vapours from deeper layers above the surface of the land, posing risk to human health. Therefore, 9 boreholes were made on the plots centrally located in the given group of residential plots within a given contamination plume. Samples were taken at the depths greater than $0.25 \mathrm{~m}$, i.e., at the depths where contamination was expected to occur. Location of the boreholes along with the depth of the sampling are presented in Figure 4.

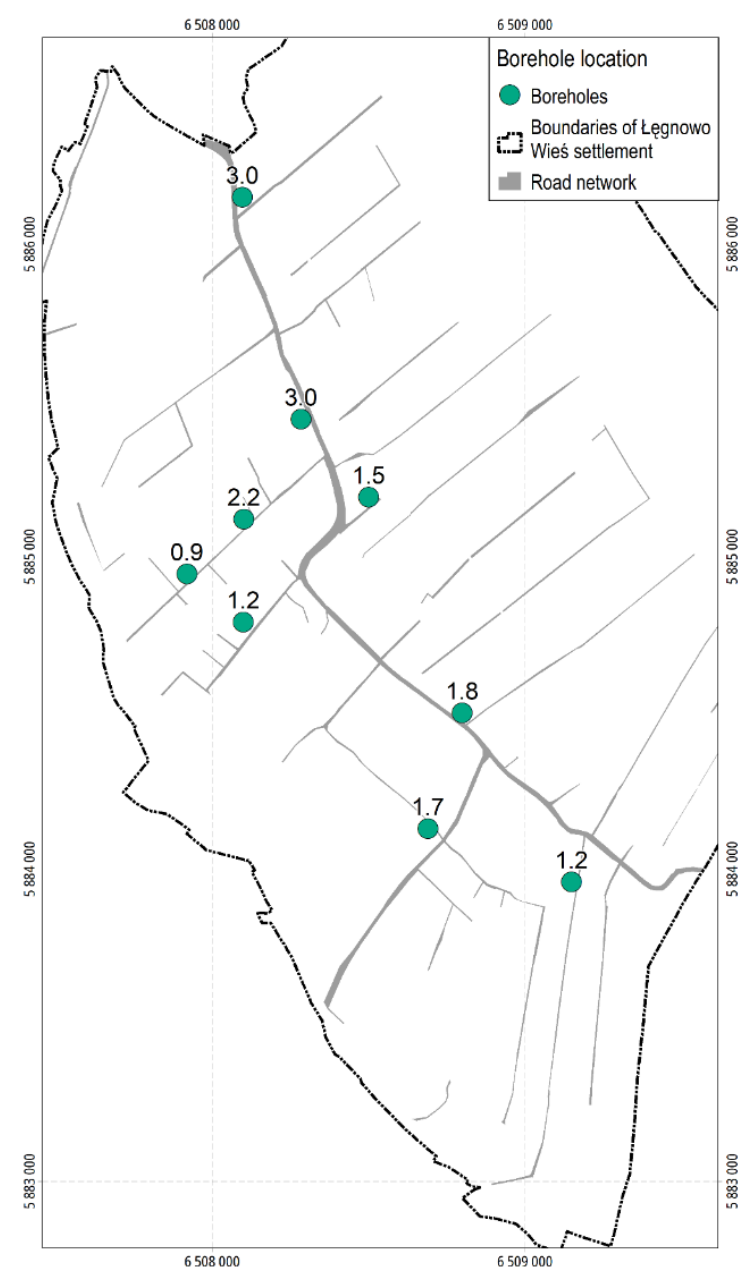

Figure 4. Location of boreholes in the residential development area of $€ W S$ (the number above the marked borehole means a soil sampling depth).

The substances for health risk analysis were selected, taking into consideration the location and boundaries of the groundwater contamination plumes in relation to the contamination sources. At the same time, it was indicated which substances should be determined in soil samples taken from the surface layer in particular sectors and which from the deeper layers (boreholes, volatile substances). This approach allowed selecting substances for risk assessment specifically for each sector of the residential area. It resulted in limiting the number of the analysed contaminants necessary to carry out the health risk assessment. The substance assignment is presented in Table 2. 
Table 2. Assignment of substances to contamination sources and plumes, broken down into substances taken from the surface layer and deeper layers.

\begin{tabular}{|c|c|c|c|c|c|c|}
\hline \multirow{2}{*}{$\begin{array}{l}\text { Sector } \\
\text { No. }{ }^{a}\end{array}$} & \multirow{2}{*}{$\begin{array}{c}\text { Area } \\
\text { (ha) }\end{array}$} & \multirow{2}{*}{$\begin{array}{l}\text { Plume } \\
\text { No. }\end{array}$} & \multirow{2}{*}{ Contamination Sources } & \multirow{2}{*}{$\begin{array}{l}\text { Substances-Soil Surface Layer } \\
(0-0.25 \mathrm{~m})\end{array}$} & $\begin{array}{l}\text { Number } \\
\text { of Boreholes }\end{array}$ & Volatiles \\
\hline & & & & & \multicolumn{2}{|c|}{ Soil Layers Below $0.25 \mathrm{~m}$ Depth } \\
\hline 11 & 1.6669 & 1 & $\begin{array}{c}\text { Incineration site in Żółwino } \\
\text { with waste from heat and } \\
\text { power plant }\end{array}$ & $\begin{array}{l}\text { PAHs (16 USEPA-regulated PAHs) }{ }^{b} \text {, } \\
\text { phenol, metals }{ }^{c} \text { and arsenic (As) }\end{array}$ & 1 & $\begin{array}{l}\text { PAHs (anthracene, } \\
\text { acenaphthene, fluorene, } \\
\text { pyrene, naphthalene, } \\
\text { benzo(a)anthracene) }\end{array}$ \\
\hline
\end{tabular}

$21 \quad 0.7400$

\begin{tabular}{|c|c|c|c|}
\hline & & 2 & Zielona landfill \\
\hline 22 & 1.5726 & & \\
\hline 23 & 1.3557 & & \\
\hline 24 & 1.9670 & & \\
\hline 25 & 1.8549 & & \\
\hline 31 & 0.5320 & \multirow{5}{*}{3} & \multirow{5}{*}{$\begin{array}{l}\text { Nitrobenzene pocket or } \\
\text { dinitrotoluene installation }\end{array}$} \\
\hline 32 & 1.7503 & & \\
\hline 33 & 1.7314 & & \\
\hline 34 & 1.3277 & & \\
\hline 35 & 1.7811 & & \\
\hline 41 & 1.2494 & \multirow{7}{*}{4} & \multirow{7}{*}{$\begin{array}{c}\text { Central part of Zachem CP, } \\
\text { incl. aniline sludge, Lisia } \\
\text { landfill, epichlorohydrin } \\
\text { (EPI) sediment pond }\end{array}$} \\
\hline 42 & 1.4752 & & \\
\hline 43 & 1.6802 & & \\
\hline 44 & 1.8907 & & \\
\hline 45 & 1.6507 & & \\
\hline 46 & 1.3698 & & \\
\hline 47 & 1.8290 & & \\
\hline 51 & 1.6121 & 5 & $\begin{array}{l}\text { Central part of the Zachem } \\
\mathrm{CP} \text {, incl. aniline sludge, } \\
\text { Lisia landfill, } \\
\text { epichlorohydrin (EPI) } \\
\text { sediment pond }\end{array}$ \\
\hline
\end{tabular}

PAHs (16 USEPA-regulated

PAHs) ${ }^{b}$, metals ${ }^{c}$ and As, phenol, chlorophenols, toluene, aniline, chloroaniline, toluidine,

2-phenylphenol, ethylene glycol, diphenyl sulphone, trichloroethene (TCE), tetrachloroethene (PCE), octylphenols

PAHs (16 USEPA-regulated PAHs) ${ }^{b}$, phenol, nitrobenzene, o-nitrotoluene, dinitrotoluene mixture $(2,4 / 2,6-)$

Aniline, chloroaniline, epichlorohydrin, toluenediamine

(TDA), toluene diisocyanate (TDI), phenol, PAHs (16

USEPA-regulated PAHs) ${ }^{b}$ nitrobenzene, toluidine, o-nitrotoluene, dinitrotoluene mixture $(2,4 / 2,6-)$, toluene

\section{Aniline, chloroaniline,}

epichlorohydrin, toluenediamine

(TDA), toluene diisocyanate (TDI), phenol, PAHs (16

USEPA-regulated PAHs ${ }^{b}$ ), nitrobenzene, toluidine, o-nitrotoluene, dinitrotoluene mixture $(2,4 / 2,6-)$
PAHs (anthracene, acenaphthene, fluorene, pyrene, naphthalene, benzo(a)anthracene), toluene

${ }^{a}$ : The first digit is the number of the groundwater contamination plume and the second one is the sequential sector number assigned to the plume. ${ }^{\mathrm{b}}$ : 16 PAHs: naphthalene, acenaphthylene, acenaphthene, fluorene, phenanthrene, anthracene, fluoranthene, pyrene, benzo(a)anthracene, chrysene, benzo(b)fluoranthene, benzo(k)fluoranthene, benzo(a)pyrene, dibenzo(a,h)anthracene, benzo(g,h,i)perylene, indeno(1,2,3-cd)pyrene. ${ }^{c}$ Metals: barium (Ba), chromium $(\mathrm{Cr})$, tin $(\mathrm{Sn})$, zinc $(\mathrm{Zn})$, cadmium $(\mathrm{Cd})$, cobalt $(\mathrm{Co})$, copper $(\mathrm{Cu})$, molybdenum $(\mathrm{Mo})$, nickel $(\mathrm{Ni})$, lead $(\mathrm{Pb})$, mercury $(\mathrm{Hg})$.

Additionally, based on the reports of Czop et al. [36,37] and Arcadis [38], 6 backyards with wells from which water was used for watering home crops were selected, and one composite soil sample was taken from the surface layer (up to the depth of $0.25 \mathrm{~m}$ ) in each of them. Location of the backyards with the marked wells (K02, K11, K26, K30, K31 and K33) is shown in Figure 5. The substances determined in the surface soil of the analysed backyards, assigned to a particular sector and plume number, are presented in Table 3. 


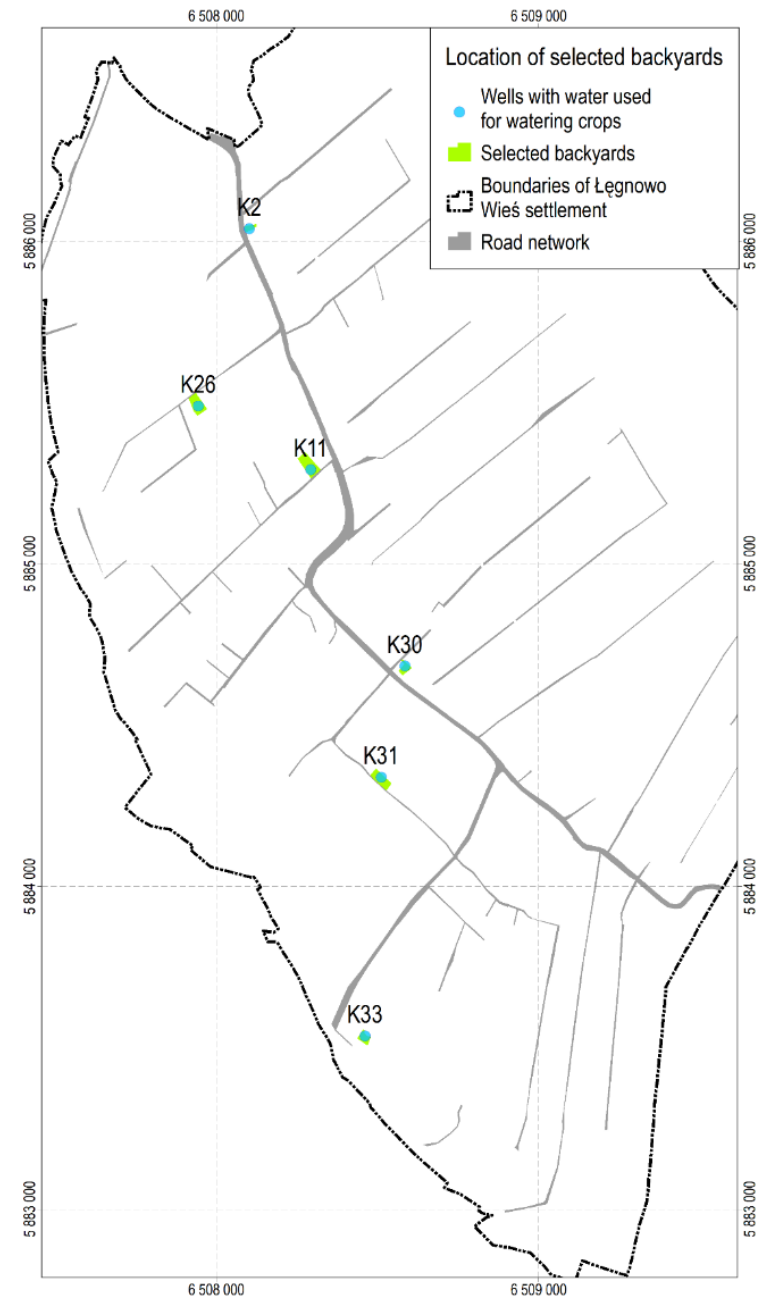

Figure 5. Location of backyards with marked wells.

Table 3. Substances determined in the surface soil of the backyards, assigned to the sector and plume number (based on Czop et al. [36,37] and Arcadis [38].

\begin{tabular}{|c|c|c|c|c|}
\hline $\begin{array}{c}\text { Backyard } \\
\text { (Well No.) }\end{array}$ & $\begin{array}{l}\text { Sector } \\
\text { No. }\end{array}$ & $\begin{array}{l}\text { Area } \\
\left(\mathrm{m}^{2}\right)\end{array}$ & $\begin{array}{l}\text { Plume } \\
\text { No. }\end{array}$ & Substances Determined in the Soil Surface Layer $(0-0.25 \mathrm{~m})$ \\
\hline K02 & 51 & 522.2 & 5 & 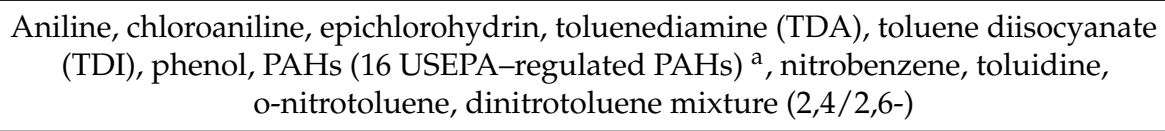 \\
\hline K11 & 44 & 2568.0 & \multirow{2}{*}{4} & \multirow{2}{*}{$\begin{array}{l}\text { Aniline, chloroaniline, epichlorohydrin, toluenediamine (TDA), toluene diisocyanate } \\
\text { (TDI), phenol, PAHs (16 USEPA-regulated PAHs) }{ }^{\text {a }} \text {, nitrobenzene, toluidine, } \\
\text { o-nitrotoluene, dinitrotoluene mixture }(2,4 / 2,6-) \text {, toluene }\end{array}$} \\
\hline K26 & 46 & 2080.0 & & \\
\hline K30 & 25 & 856.6 & \multirow{3}{*}{2} & \multirow{3}{*}{$\begin{array}{l}\text { PAHs (16 USEPA-regulated PAHs) }{ }^{a} \text {, metals }{ }^{b} \text { and As, phenol, chlorophenols, } \\
\text { toluene, aniline, chloroaniline, toluidine, 2-phenylphenol, ethylene glycol, diphenyl } \\
\text { sulphone, trichloroethene (TCE), tetrachloroethene (PCE), octylphenols }\end{array}$} \\
\hline K31 & 23 & 1896.0 & & \\
\hline K33 & 21 & 984.7 & & \\
\hline
\end{tabular}

${ }^{a}$ : 16 PAHs (polycyclic aromatic hydrocarbons): naphthalene, acenaphthylene, acenaphthene, fluorene, phenanthrene, anthracene, fluoranthene, pyrene, benzo(a)anthracene, chrysene, benzo(b)fluoranthene, benzo(k)fluoranthene, benzo(a)pyrene, dibenzo(a,h)anthracene, benzo(g,h,i)perylene, indeno(1,2,3-cd)pyrene b: Metals: barium $(\mathrm{Ba})$, chromium $(\mathrm{Cr})$, tin $(\mathrm{Sn})$, zinc $(\mathrm{Zn})$, cadmium $(\mathrm{Cd})$, cobalt $(\mathrm{Co})$, copper $(\mathrm{Cu})$, molybdenum $(\mathrm{Mo})$, nickel $(\mathrm{Ni})$, lead $(\mathrm{Pb})$, mercury $(\mathrm{Hg})$. 


\subsection{Analytical Methods}

A total of 80 inorganic and organic substances were determined. The laboratory analyses were conducted in an accredited laboratory. The analytical methods applied for the determination of the substances are summarised in Table 4.

Table 4. Analytical methods applied for the determination of substances.

\begin{tabular}{|c|c|}
\hline Substance & Method \\
\hline 2,3-toluenediamine, 2,4-toluenediamine, 2,6-toluenediamine & ISO 11916-1: 2014-11, LC-UV \\
\hline 2,4-dinitrotoluene, 2,6-dinitrotoluene, o-nitrotoluene & ISO 11916-1: 2014-11, LC-UV \\
\hline 2-chloroanilin, 3-chloroanilin, 4-chloroanilin, aniline & DIN 38407-16: 1999-06, GC-MS \\
\hline 2-phenylphenol & $\begin{array}{l}\text { Non-standard method, } \\
\text { GC-MS-/MS }\end{array}$ \\
\hline 2-toluidine, 3-toluidine, 4-toluidine, nitrobenzene & ISO 11916-1: 2014-11, LC-UV \\
\hline Arsenic and heavy metals & PN-EN 16171:2017-02, ICP-MS \\
\hline Benzene, toluene, ethylbenzene, xylenes (BTEX) & $\begin{array}{c}\text { PN-EN ISO 22155:2016-07, } \\
\text { HS-GC-MS }\end{array}$ \\
\hline Chlorophenols & Non-standard method, GC-MS \\
\hline Diphenyl sulphone & Non-standard method, GC-MS-MS \\
\hline Epichlorohydrin & Non-standard method, HS-GC-MS \\
\hline Ethylene glycol & Non-standard method, GC-FID \\
\hline Octylphenols & $\begin{array}{l}\text { Non-standard method, } \\
\text { GC-MS-/MS }\end{array}$ \\
\hline Phenol & Non-standard method, GC-MS \\
\hline Polycyclic aromatic hydrocarbons & PN-ISO 18287:2008; GC-MS \\
\hline $\begin{array}{l}\text { Tetrachloroethene } \\
\text { Trichloroethene }\end{array}$ & NEN ISO 22155, HS-GC-MS \\
\hline Toluene diisocyanate & Non-standard method, LC-MS-MS \\
\hline $\begin{array}{l}\text { ICP-MS: inductively coupled plası } \\
\text { LC-UV: liquid chromatography-u } \\
\text { LC-MS-MS: liquid chromatography } \\
\text { detection; GC-MS-MS: gas chromat }\end{array}$ & $\begin{array}{l}\text { try; GC-MS: liquid chromatography-ma } \\
\text { MS: headspace gas chromatography-ma } \\
\text { ctrometry; GC-FID: gas chromatography } \\
\text { nass spectrometry. }\end{array}$ \\
\hline
\end{tabular}

\subsection{Health Risk Assessment (HRA)}

In most European counties, the risk-based approaches are often applied for dealing with contaminated sites [1]. In Poland, health risk assessment is applied at contaminated sites, although it is not legally binding [40].

To assess the health risk to the residents of ŁWS, the HRA2 software developed by the Institute for Ecology of Industrial Areas (IETU), was applied [41]. The HRA2 software algorithms are based on the USEPA site-specific risk assessment methodology [42-50]. This methodology has been adapted to the Polish conditions and applied in practice in Poland since 1996 [51]. The USEPA human risk assessment is also widely used outside the United States $[9,10,12,52-57]$.

The USEPA risk-based approach was also proposed for the process of contaminated land remediation in Poland [51]. Recently, its updated version has been proposed for the assessment of significant health risk [40], which is required in remediation plans and remediation project plans for contaminated soil under the Polish Environmental Protection Law (EPL), [58]. However, the risk assessment method has not been legally established as the reference one.

The site-specific HRA is based on site investigation data, including geochemical data and site-specific exposure conditions strictly related to the land use pattern. In the case of $Ł W S$ it was the residential pattern. Exposure assessment describes the variables and 
their interactions that result in the exposure to contaminants. In the carried out study three exposure pathways were analysed: (1) incidental soil and dust ingestion (e.g. through hand-to-mouth contact), (2) dermal contact with soil, and (3) inhalation of fugitive soil particles and volatiles. These exposure pathways are the main pathways taken into account in risk assessment conducted in the contaminated sites [9,12,24,57].

Exposure to the soil contaminants was quantified separately for each exposure pathway: oral Exp $p_{o}$, dermal Exp $p_{d}$ and inhalation $\operatorname{Exp}_{i n h}$, as shown in Equations (1)-(3), respectively [47-50]. The exposure was assessed separately for children and adults.

$$
\begin{aligned}
& \operatorname{Exp}_{\mathbf{o}}\left(\mathbf{m g ~ k g}^{-1} \mathbf{d}^{-1}\right)=\frac{\mathrm{C} \times \mathrm{EF} \times \mathbf{E D} \times \mathrm{IR}_{\mathbf{o}} \times \mathbf{C F}_{1} \times \mathbf{R B A}}{\mathbf{B W} \times \mathbf{A T}} \\
& \operatorname{Exp}_{\mathrm{d}}\left(\mathrm{mg} \mathrm{kg}^{-1} \mathbf{d}^{-1}\right)=\frac{\mathrm{C} \times \mathrm{EF} \times \mathrm{ED} \times \mathrm{SA} \times \mathbf{A F} \times \mathbf{A B S}_{\mathbf{d}} \times \mathrm{CF}_{1}}{\mathbf{B W} \times \mathbf{A T}} \\
& \operatorname{Exp}_{i n h}\left(\mathbf{m g ~ m} \mathbf{~ m}^{-3}\right) \frac{\mathbf{C} \times \mathbf{E F} \times \mathbf{E D} \times \mathbf{E T} \times\left(\frac{1}{\mathbf{P E F}}+\frac{1}{\mathrm{VF}}\right)}{\mathbf{A T}}
\end{aligned}
$$

\begin{tabular}{|c|c|c|}
\hline Parameter & Definition (Unit) & Value \\
\hline $\mathrm{ABS}_{\mathrm{d}}$ & dermal absorption fraction (unitless) & chemical-specific (see Table 6) \\
\hline $\mathrm{ABS}_{\mathrm{GI}}$ & gastrointestinal absorption factor (unitless) & chemical-specific (see Table 6) \\
\hline AF (adult) & soil-to-skin adherence factor $\left(\mathrm{mg} / \mathrm{cm}^{2} /\right.$ day $)$ & 0.07 \\
\hline AF (child) & soil-to-skin adherence factor $\left(\mathrm{mg} / \mathrm{cm}^{2} /\right.$ day $)$ & 0.2 \\
\hline $\mathrm{AT}_{\mathrm{N}}$ (adult) & $\begin{array}{l}\text { averaging time for non-carcinogens (days); } \\
\qquad \mathrm{AT}_{\mathrm{N}}=\mathrm{ED} \times 365 \text { days }\end{array}$ & 8760 \\
\hline $\mathrm{AT}_{\mathrm{N}}($ child $)$ & $\begin{array}{l}\text { averaging time for non-carcinogens (days); } \\
\qquad \mathrm{AT}_{\mathrm{N}}=\mathrm{ED} \times 365 \text { days }\end{array}$ & 2190 \\
\hline $\mathrm{AT}_{\mathrm{C}}$ & $\begin{array}{l}\text { averaging time (carcinogens) (days); } \\
\quad \mathrm{AT}_{\mathrm{C}}=70 \text { years } \times 365 \text { days }\end{array}$ & 25,550 \\
\hline BW (adult) & body weight $(\mathrm{kg})$ & 70 \\
\hline BW (child) & body weight $(\mathrm{kg})$ & 15 \\
\hline $\mathrm{C}$ & contaminant content in the surface soil & (see Supplementary Material 1; Table S1a,b) \\
\hline $\mathrm{CF}_{1}$ & conversion factor $(\mathrm{kg} / \mathrm{mg})$ & $1 \times 10^{-6}$ \\
\hline $\mathrm{CSF}_{\mathrm{d}}$ & dermally adjusted cancer slope factor $(\mathrm{mg} / \mathrm{kg} / \text { day })^{-1}$ & chemical-specific $\left(\mathrm{CSF}_{\mathrm{d}}=\mathrm{CSF}_{\mathrm{o}} / \mathrm{ABS}_{\mathrm{GI}}\right)$ \\
\hline $\mathrm{CSF}_{\mathrm{O}}$ & oral cancer slope factor $(\mathrm{mg} / \mathrm{kg} / \text { day })^{-1}$ & chemical-specific (see Table 6) \\
\hline ED (adult) & exposure duration (years) & 24 \\
\hline ED (child) & exposure duration (years) & 6 \\
\hline $\mathrm{EF}$ & exposure frequency (days/year) & 350 \\
\hline ET & exposure time in a day $(\mathrm{h} / \mathrm{h})$ & 1 ( $24 \mathrm{~h} / 24 \mathrm{~h}$, i.e. whole day) \\
\hline $\mathrm{IR}_{\mathrm{O}}$ (adult) & ingestion rate (mg/day) & 100 \\
\hline $\mathrm{IR}_{\mathrm{o}}$ (child) & ingestion rate (mg/day) & 200 \\
\hline IUR & inhalation unit risk $\left(\mathrm{mg} / \mathrm{m}^{3}\right)^{-1}$ & chemical-specific (see Table 6) \\
\hline PEF & particulate emission factor $\left(\mathrm{m}^{3} / \mathrm{kg}\right)$ & $\begin{array}{l}\text { sector/backyard area-specific; calculated according } \\
\text { to USEPA (2002) }\end{array}$ \\
\hline RBA & relative bioavailability factor & 0.6 for As; 1 for other substances \\
\hline RfC & inhalation reference concentration $\left(\mathrm{mg} / \mathrm{m}^{3}\right)$ & chemical-specific (see Table 6) \\
\hline $\operatorname{RfD}_{\mathrm{d}}$ & dermally adjusted reference dose ( $\mathrm{mg} / \mathrm{kg} /$ day) & chemical-specific $\left(\mathrm{RfD}_{\mathrm{d}}=\mathrm{RfD}_{\mathrm{o}} \times \mathrm{ABS}_{\mathrm{GI}}\right)$ \\
\hline $\mathrm{RfD}_{\mathrm{o}}$ & oral reference dose $\left(\mathrm{mg} / \mathrm{m}^{3}\right)$ & chemical-specific (see Table 6) \\
\hline SA (adult) & skin surface area exposed $\left(\mathrm{cm}^{2}\right)$ & 5700 \\
\hline SA (child) & skin surface area exposed $\left(\mathrm{cm}^{2}\right)$ & 2800 \\
\hline $\mathrm{TR}_{\mathrm{C}}$ & cancer target risk & $1 \times 10^{-5}[39]$ \\
\hline $\mathrm{TR}_{\mathrm{N}}$ & non-cancer target risk & 1 \\
\hline VF & volatile factor $\left(\mathrm{m}^{3} / \mathrm{kg}\right)$ & $\begin{array}{l}\text { chemical-specific and sector/backyard area-specific; } \\
\text { calculated according to USEPA }[48,50]\end{array}$ \\
\hline
\end{tabular}

The applied parameter values are presented in Table 5.

Table 5. Parameter values applied for health risk assessment in ŁWS [43,44,48,49]. 
Concerning carcinogens with a mutagenic mode of action, the age dependent adjustment factors (ADAFs) were applied for calculating the residential pathway-specific exposure. ADAFs are related to the susceptibility to early-life exposure to such carcinogens. They refer to the following human life periods: $0-2$ years $\left(\mathrm{ADAF}_{0-2}=10\right), 2-6$ years $\left(\mathrm{ADAF}_{2-6}=3\right), 6-16$ years $\left(\mathrm{ADAF}_{6-16}=3\right)$ and $16-30$ years $\left(\mathrm{ADAF}_{16-30}=1\right)[50,59]$.

Table 6. Chemical-specific parameter values $[49,50,60]$.

\begin{tabular}{|c|c|c|c|c|c|c|c|c|}
\hline Substance & & $\begin{array}{c}\text { CAS } \\
\text { Number }\end{array}$ & $\begin{array}{c}\operatorname{RfD}_{\mathrm{o}} \\
\text { (mg/kg/day) }\end{array}$ & $\begin{array}{c}\mathrm{RfC} \\
\left(\mathrm{mg} / \mathrm{m}^{3}\right)\end{array}$ & $\begin{array}{c}\mathrm{CSF}_{\mathrm{o}} \\
(\mathrm{mg} / \mathrm{kg} / \text { day })^{-1}\end{array}$ & $\begin{array}{c}\text { IUR } \\
\left(\mu \mathrm{g} / \mathrm{m}^{3}\right)^{-1}\end{array}$ & $\begin{array}{c}\mathrm{ABS}_{\mathrm{GI}} \\
\text { (Unitless) }\end{array}$ & $\begin{array}{c}\mathrm{ABS}_{\mathrm{d}} \\
\text { (Unitless) }\end{array}$ \\
\hline \multicolumn{9}{|c|}{ Metals and metalloids } \\
\hline Arsenic & & 007440-38-2 & $3.0 \times 10^{-4}$ & $1.5 \times 10^{-5}$ & 1.50 & $4.3 \times 10^{-3}$ & 1 & 0.03 \\
\hline Barium & & 007440-39-3 & $2.0 \times 10^{-1}$ & $5.0 \times 10^{-4}$ & NA & NA & 0.07 & 0.01 \\
\hline Cadmium & & 007440-43-9 & $1.0 \times 10^{-3}$ & $1.0 \times 10^{-5}$ & NA & $1.8 \times 10^{-3}$ & 0.025 & 0.001 \\
\hline Chromium (III) & & 016065-83-1 & 1.5 & NA & NA & NA & 0.013 & 0.01 \\
\hline Chromium (VI) & M & 018540-29-9 & $3.0 \times 10^{-3}$ & $1.0 \times 10^{-4}$ & $5.00 \times 10^{-1}$ & $8.4 \times 10^{-2}$ & 0.025 & 0.01 \\
\hline Cobalt & & 007440-48-4 & $3.0 \times 10^{-4}$ & $6.0 \times 10^{-6}$ & NA & $9.0 \times 10^{-3}$ & 1 & 0.01 \\
\hline Copper & & 007440-50-8 & $4.0 \times 10^{-2}$ & NA & NA & NA & 1 & 0.01 \\
\hline Mercury & & 007487-94-7 & $3.0 \times 10^{-4}$ & $3.0 \times 10^{-4}$ & NA & NA & 0.07 & 0.01 \\
\hline Molybdenum & & 007439-98-7 & $5.0 \times 10^{-3}$ & NA & NA & NA & 1 & 0.01 \\
\hline Nickel & & 007440-02-0 & $2.0 \times 10^{-2}$ & $9.0 \times 10^{-5}$ & NA & $2.6 \times 10^{-4}$ & 0.04 & 0.01 \\
\hline Tin & & 007440-31-5 & $6.0 \times 10^{-1}$ & NA & NA & NA & 1 & 0.01 \\
\hline Zinc & & 007440-66-6 & $3.0 \times 10^{-1}$ & NA & NA & NA & 1 & 0.01 \\
\hline \multicolumn{9}{|c|}{ Polycyclic aromatic hydrocarbons (PAHs) } \\
\hline Acenaphthene & & 000083-32-9 & $6.0 \times 10^{-2}$ & NA & NA & NA & 1 & 0.13 \\
\hline Acenaphthylene * & & 000208-96-8 & NA & NA & NA & NA & 1 & 0.13 \\
\hline Anthracene & & 000120-12-7 & $3.0 \times 10^{-1}$ & NA & NA & NA & 1 & 0.13 \\
\hline Benzo(a)anthracene & M & $000056-55-3$ & NA & NA & $1.00 \times 10^{-1}$ & $6.0 \times 10^{-5}$ & 1 & 0.13 \\
\hline Benzo(a)pyrene & M & 000050-32-8 & $3.0 \times 10^{-4}$ & $2.0 \times 10^{-6}$ & 1.00 & $6.0 \times 10^{-4}$ & 1 & 0.13 \\
\hline Benzo(b)fluoranthene & M & 000205-99-2 & NA & NA & $1.00 \times 10^{-1}$ & $6.0 \times 10^{-5}$ & 1 & 0.13 \\
\hline Benzo(g,h,i)perylene * & & 000191-24-2 & NA & NA & NA & NA & 1 & 0.13 \\
\hline Benzo(k)fluoranthene & M & 000207-08-9 & NA & NA & $1.00 \times 10^{-2}$ & $6.0 \times 10^{-6}$ & 1 & 0.13 \\
\hline Chrysene & M & 000218-01-9 & NA & NA & $1.00 \times 10^{-3}$ & $6.0 \times 10^{-7}$ & 1 & 0.13 \\
\hline Dibenzo(a,h)anthracene & M & 000053-70-3 & NA & NA & 1.00 & $6.0 \times 10^{-4}$ & 1 & 0.13 \\
\hline Fluoranthene & & 000206-44-0 & $4.0 \times 10^{-2}$ & NA & NA & NA & 1 & 0.13 \\
\hline Fluorene & & $000086-73-7$ & $4.0 \times 10^{-2}$ & NA & NA & NA & 1 & 0.13 \\
\hline Phenanthrene * & & 000085-01-8 & NA & NA & NA & NA & 1 & 0.13 \\
\hline Indeno(1,2,3-cd)pyrene & M & 000193-39-5 & NA & NA & $1.00 \times 10^{-1}$ & $6.0 \times 10^{-5}$ & 1 & 0.13 \\
\hline Naphthalene & & 000091-20-3 & $2.0 \times 10^{-2}$ & $3.0 \times 10^{-3}$ & NA & $3.4 \times 10^{-5}$ & 1 & 0.13 \\
\hline Pyrene & & 000129-00-0 & $3.0 \times 10^{-2}$ & NA & NA & NA & 1 & 0.13 \\
\hline \multicolumn{9}{|l|}{ Other substances } \\
\hline 3,5-dichlorophenol * & & 000591-35-5 & NA & NA & NA & NA & NA & NA \\
\hline Phenol & & 000108-95-2 & $3.0 \times 10^{-1}$ & $2.0 \times 10^{-1}$ & NA & NA & 1 & 0.1 \\
\hline
\end{tabular}

NA: not available; $\mathrm{M}$ : mutagenic substance; $\mathrm{RfD}_{\mathrm{O}}$ : oral reference dose; $\mathrm{CSF}_{\mathrm{o}}$ : oral cancer slope factor; RfC: reference concentration; IUR: inhalation unit risk; $\mathrm{ABS}_{\mathrm{GI}}$ : gastrointestinal absorption factor; $\mathrm{ABS}_{\mathrm{d}}$ : dermal absorption fraction; *: substance skipped in the health risk assessment due to the lack of data on its toxicity measures.

The health risks were characterised separately for non-carcinogenic and carcinogenic effects.

The non-cancer risk was estimated as the pathway-specific hazard quotient (oral $\mathrm{HQ}_{\mathrm{o}}$, dermal $\mathrm{HQ}_{\mathrm{d}}$ and inhalation $\mathrm{HQ}_{\mathrm{inh}}$ ) through dividing the pathway-specific exposure by the relevant reference dose (oral $\mathrm{RfD}_{\mathrm{o}}$, dermal $\mathrm{RfD}_{\mathrm{d}}$ ) or the inhalation reference concentration (RfC), using Equations (4)-(6) [42,48,50].

$$
\mathrm{HQ}_{\mathrm{o}}=\frac{\operatorname{Exp}_{\mathrm{o}}}{\operatorname{RfD}_{\mathrm{o}}}
$$




$$
\begin{aligned}
H Q_{d} & =\frac{\operatorname{Exp}_{d}}{\operatorname{RfD}_{d}} \\
H Q_{\text {inh }} & =\frac{\operatorname{Exp}_{\text {inh }}}{\operatorname{RfC}}
\end{aligned}
$$

Summing the pathway-specific HQs, the hazard index (HI) for a given non-carcinogen was obtained, using Equation (7).

$$
\mathbf{H I}=\mathrm{HQ}_{\mathbf{o}}+\mathrm{HQ}_{\mathbf{d}}+\mathrm{HQ}_{\mathrm{inh}}
$$

The total hazard index (total HI) was obtained by summing the HIs calculated for all analysed non-carcinogens, as shown in Equation (8).

$$
\text { Total } \mathbf{H I}=\sum_{\mathbf{i}=1}^{\mathbf{n}} \mathbf{H I}_{\mathbf{i}}
$$

The total HI >1 means that there might be potential adverse health effects (USEPA, 1989).

Concerning the cancer risk, the pathway-specific cancer risk (oral $\mathrm{CR}_{\mathrm{o}}$, dermal $\mathrm{CR}_{\mathrm{d}}$ and inhalation $\mathrm{CR}_{\text {inh }}$ ) was estimated by the multiplication of the pathway-specific exposure and the relevant cancer slope factor (oral $\mathrm{CSF}_{\mathrm{o}}$, dermal $\mathrm{CSF}_{\mathrm{d}}$ ) or the inhalation unit risk (IUR), using Equations (9)-(11), [42,48,50].

$$
\begin{aligned}
\mathrm{CR}_{\mathrm{o}} & =\operatorname{Exp}_{\mathrm{o}} \times \mathrm{CSF}_{\mathrm{o}} \\
\mathrm{CR}_{\mathbf{d}} & =\operatorname{Exp}_{\mathbf{d}} \times \mathrm{CSF}_{\mathrm{d}} \\
\mathrm{CR}_{\text {inh }} & =\operatorname{Exp}_{\mathrm{inh}} \times \mathrm{IUR}
\end{aligned}
$$

The cancer risk (CR) for a given non-carcinogen was obtained by summing the pathway-specific CRs, as shown in Equation (12).

$$
\mathrm{CR}=\mathrm{CR}_{\mathbf{o}}+\mathrm{CR}_{\mathrm{d}}+\mathrm{CR}_{\mathrm{inh}}
$$

The total cancer risk was estimated as a sum of CRs obtained for all analysed carcinogens, as shown in Equation (13).

$$
\text { Total } \mathbf{C R}=\sum_{\mathbf{i}=1}^{\mathbf{n}} \mathbf{C R}_{\mathbf{i}}
$$

The CRs were compared with the acceptable cancer risk values. The value of $1 \times 10^{-5}$ (one in a hundred thousand) was used as the acceptable cancer risk for the individual carcinogen, as it is required in Poland [39]. In contrast, the value of $1 \times 10^{-1}$ was used as the maximum acceptable total cancer risk according to the USEPA approach $[43,44]$, and this was used by other authors as well $[6,54,61,62]$.

The HRA results obtained in this study are presented for both types of receptors, i.e., children and adults for non-cancer effects and aggregate residents for cancer effects according to USEPA approach $[45,47,48]$. The aggregate receptor means an individual who is exposed in his/her childhood (for 6 years) and adult life (for 24 years). Aggregate cancer risk is calculated as the sum of child cancer risk and adult cancer risk $[45,47,48,63]$. The health risks were assessed separately for each sampling sector and each selected backyard.

\subsection{Uncertainty in the Risk Assessment Process}

Uncertainties are inherent in the risk assessment process and cannot be avoided. Uncertainties may be associated with data and analyses at each step of the risk assessment, e.g., the selection of substances, toxicity assessment and/or exposure assessment. Risk assessment results should be presented with the accompanying evaluation of the key uncertainties specific to the analysed chemicals and exposure pathways in order to support proper risk management decisions $[64,65]$. 
Uncertainties may be expressed either quantitatively or qualitatively, however, it depends on the applied risk assessment methodology-deterministic or probabilistic. In deterministic risk assessment, i.e., when relying on point values as inputs and presenting results also as point values, uncertainties may be discussed only qualitatively or semiquantitatively. As for probabilistic risk analysis, using multiple risk estimates provides the likelihood of various risk levels, allowing uncertainties to be expressed quantitatively [66].

The health risk assessment conducted in the study is deterministic. Therefore, uncertainties could be addressed only qualitatively. This risk assessment applies conservative assumptions to obtain risk estimates protective for most of the potential receptors [64]. It uses default exposure parameter values that are selected to produce an overall estimate of exposure, which is at the higher end of the range of plausible exposures. Such an exposure is referred to as the reasonable maximum exposure (RME) and is defined as "the highest exposure that is reasonably expected to occur at a site" [42].

\subsection{Developing the Site-Specific Health Risk-Based Target Levels (HRBTLs) for Soil Contaminants}

Site-specific health risk-based target levels are estimated for the individual contaminants using the risk estimates obtained in the site-specific HRA [50,51,67]. They are calculated separately for non-cancer and cancer effects, using Equation (14) [50].

$$
\text { HRBTL }=\mathrm{C} \times \frac{\mathrm{TR}}{\text { Calculated risk }}
$$

$\mathrm{C}$ : chemical content in soil $(\mathrm{mg} / \mathrm{kg})$

HRBTL: health risk-based target level

TR: target risk (non-cancer target risk-TRN-HQ/HI or cancer target risk-TRC).

The HRBTLs were estimated for the most sensitive human receptors under the residential exposure scenario, i.e., children for non-cancer effects and aggregate residents for cancer effects $[45,50]$. In the case of non-cancer effects, the child life stage from birth to 6 years old is considered to be the most sensitive life stage. Due to the higher intake rate of soil by children and their lower body weight, the estimated exposure in children is greater than in adults $[45,48]$. For carcinogenic effects, the aggregate residents are considered to be sensitive receptors because the exposures are averaged over the whole (70 years) lifetime $[45,48,63]$.

In the study, the HRBTLs correspond to the $\mathrm{TR}_{\mathrm{N}}(\mathrm{HQ})$ of 1 for non-carcinogens as it is required by USEPA [50] and to the $\mathrm{TR}_{C}$ of $1 \times 10^{-5}$ for carcinogens, according to [39]. If the contaminant produces both non-cancer and cancer effects, the non-cancer and cancer HRBTLs are compared and the lower of them is chosen as the final HRBTL.

\section{Results and Discussion}

\subsection{Soil Contamination in Sampling Sectors and Backyards}

The health risk assessment focused on substances, the content of which in the surface soil was equal to or higher than their limit of quantification (LOQ). The content of the volatiles determined in the deeper layer was not taken into account because only in one sample (sector 51) was the content of benzo(a)anthracene and in two samples was the content of pyrene (sectors 25 and 51) higher than their LOQ but lower than in the surface layer. The content of 3,5-dichlorophenol was equal to its LOQ in only one sample, in other sectors being lower than its LOQ. Taking into account that the relevant toxicity value is unavailable, this substance was not considered in the HRA. Ultimately, the content of metals, arsenic, PAHs and phenol in the surface soil was the input data for the assessment of health risk to ŁWS residents (see Supplementary Material 1; Table S1a,b).

The descriptive statistics of these substances, along with their worldwide background mean content, are shown in Table 7. The coefficient of variation (CV) estimated for As and heavy metals shows lower content variability of these elements. The CVs for all of them are below 0.6. The CV estimated for PAHs shows very high content variability of all PAHs, especially in the sampling sectors. The highest $\mathrm{CV}$ is observed for fluorene $(\mathrm{CV}=3.01)$ and 
for naphthalene, anthracene, acenaphthene, phenanthrene and fluoranthene (CV above 2). Very high variability in the content of all PAHs may indicate a different origin of PAH contamination than from the Zachem CP.

When compared with the worldwide background mean content, it can be observed that in the analysed sectors and backyards the mean content of arsenic and all heavy metals, except for Zn, was lower than the relevant background content. The copper content in the backyard soil was only slightly higher than the corresponding background level. The mean contents of arsenic and most heavy metals are below their background values, which indicates that these elements are of natural origin.

To assess soil contamination with PAHs, the criteria for the sum of PAHs proposed by Maliszewska-Kordybach [69] were applied. According to them, the sum of 16 PAHs' content in the soil below $0.2 \mathrm{mg} / \mathrm{kg}$ indicates that the soil is considered to be uncontaminated. The sum of 16 PAHs' content is shown in Table 8.

Table 7. Descriptive statistics of substances analysed in sectors and backyards.

\begin{tabular}{|c|c|c|c|c|c|c|c|c|}
\hline Substance & $\mathbf{N}$ & $\begin{array}{l}\text { Minimum } \\
(\mathrm{mg} / \mathrm{kg})\end{array}$ & $\begin{array}{l}\text { Maximum } \\
(\mathrm{mg} / \mathrm{kg})\end{array}$ & $\begin{array}{c}\text { Mean } \\
(\mathrm{mg} / \mathrm{kg})\end{array}$ & $\begin{array}{c}\text { GM } \\
(\mathrm{mg} / \mathrm{kg})\end{array}$ & SD & $\mathrm{CV}$ & $\begin{array}{c}\text { Worldwide Background Mean } \\
\text { Content (mg/kg) [68] }\end{array}$ \\
\hline \multicolumn{9}{|c|}{ Sampling sectors } \\
\hline \multicolumn{9}{|c|}{ Arsenic and heavy metals } \\
\hline As & 7 & 1.64 & 4.37 & 2.72 & 2.59 & 0.94 & 0.35 & 4.7 \\
\hline $\mathrm{Ba}$ & 7 & 40.20 & 127.00 & 81.56 & 77.30 & 27.49 & 0.34 & 362 \\
\hline Co & 7 & 1.28 & 3.95 & 2.48 & 2.34 & 0.88 & 0.35 & 6.9 \\
\hline $\mathrm{Cr}$ & 7 & 4.81 & 14.60 & 8.62 & 8.11 & 3.33 & 0.39 & 42 \\
\hline $\mathrm{Cu}$ & 7 & 7.52 & 14.20 & 10.44 & 10.24 & 2.21 & 0.21 & 14 \\
\hline $\mathrm{Hg}$ & 7 & 0.05 & 0.05 & 0.05 & 0.05 & 0.00 & NA & 0.1 \\
\hline $\mathrm{Ni}$ & 7 & 3.22 & 15.00 & 7.34 & 6.59 & 3.88 & 0.53 & 18 \\
\hline $\mathrm{Pb}$ & 7 & 12.00 & 25.70 & 17.31 & 16.74 & 4.90 & 0.28 & 25 \\
\hline Sn & 7 & 0.50 & 1.49 & 0.84 & 0.75 & 0.45 & 0.54 & - \\
\hline $\mathrm{Zn}$ & 7 & 54.70 & 156.00 & 102.74 & 97.26 & 35.25 & 0.34 & 62 \\
\hline \multicolumn{9}{|c|}{ PAHs and phenol } \\
\hline ACTE & 20 & 0.0125 & 0.7390 & 0.0554 & 0.0202 & 0.1614 & 2.92 & - \\
\hline ACTY & 20 & 0.0125 & 0.0760 & 0.0260 & 0.0218 & 0.0166 & 0.64 & - \\
\hline ANT & 20 & 0.0125 & 2.9500 & 0.3076 & 0.0846 & 0.7410 & 2.41 & - \\
\hline $\mathrm{B}(\mathrm{a}) \mathrm{A}$ & 20 & 0.0125 & 6.3800 & 0.8670 & 0.3214 & 1.5868 & 1.83 & - \\
\hline $\mathrm{B}(\mathrm{a}) \mathrm{P}$ & 20 & 0.0125 & 5.0980 & 0.8231 & 0.3439 & 1.2643 & 1.54 & - \\
\hline $\mathrm{B}(\mathrm{b}) \mathrm{F}$ & 20 & 0.0125 & 7.5100 & 1.1633 & 0.4686 & 1.7990 & 1.55 & - \\
\hline $\mathrm{B}(\mathrm{g}, \mathrm{h}, \mathrm{i}) \mathrm{P}$ & 20 & 0.0125 & 2.8800 & 0.5270 & 0.2480 & 0.7133 & 1.35 & - \\
\hline $\mathrm{B}(\mathrm{k}) \mathrm{F}$ & 20 & 0.0125 & 2.5900 & 0.4171 & 0.1896 & 0.6256 & 1.50 & - \\
\hline CHR & 20 & 0.0125 & 6.7200 & 0.9126 & 0.3412 & 1.5991 & 1.75 & - \\
\hline $\mathrm{D}(\mathrm{a}, \mathrm{h}) \mathrm{A}$ & 20 & 0.0125 & 0.8780 & 0.1112 & 0.0358 & 0.2131 & 1.92 & - \\
\hline FEN & 20 & 0.0125 & 11.4000 & 0.8796 & 0.2752 & 2.4875 & 2.83 & - \\
\hline FLU & 20 & 0.0125 & 0.9720 & 0.0706 & 0.0238 & 0.2127 & 3.01 & - \\
\hline FLUA & 20 & 0.0125 & 14.0000 & 1.4941 & 0.5718 & 3.0549 & 2.04 & - \\
\hline $\mathrm{I}(1,2,3-\mathrm{cd}) \mathrm{P}$ & 20 & 0.0125 & 3.6600 & 0.5970 & 0.2762 & 0.8567 & 1.43 & - \\
\hline NAF & 20 & 0.0125 & 0.4910 & 0.0522 & 0.0177 & 0.1249 & 2.40 & - \\
\hline PIR & 20 & 0.0125 & 10.3000 & 1.1927 & 0.4875 & 2.2556 & 1.89 & - \\
\hline Phenol & 20 & 0.0050 & 0.0100 & 0.0053 & 0.0052 & 0.0011 & 0.21 & - \\
\hline \multicolumn{9}{|c|}{ Backyards } \\
\hline \multicolumn{9}{|c|}{ Arsenic and heavy metals } \\
\hline As & 3 & 2.53 & 3.94 & 3.26 & 3.21 & 0.71 & 0.22 & 4.7 \\
\hline $\mathrm{Ba}$ & 3 & 46.20 & 125.00 & 82.13 & 75.73 & 39.85 & 0.49 & 362 \\
\hline $\mathrm{Co}$ & 3 & 1.85 & 3.30 & 2.48 & 2.41 & 0.74 & 0.30 & 6.9 \\
\hline $\mathrm{Cr}$ & 3 & 5.26 & 11.30 & 8.00 & 7.62 & 3.06 & 0.38 & 42 \\
\hline $\mathrm{Cu}$ & 3 & 9.40 & 18.10 & 14.57 & 14.02 & 4.57 & 0.31 & 14 \\
\hline $\mathrm{Hg}$ & 3 & 0.05 & 0.12 & 0.07 & 0.07 & 0.04 & 0.57 & 0.1 \\
\hline $\mathrm{Ni}$ & 3 & 4.60 & 10.40 & 7.29 & 6.90 & 2.92 & 0.40 & 18 \\
\hline $\mathrm{Pb}$ & 3 & 14.50 & 31.00 & 21.83 & 20.79 & 8.40 & 0.38 & 25 \\
\hline Sn & 3 & 0.50 & 1.44 & 1.11 & 1.00 & 0.53 & 0.48 & - \\
\hline $\mathrm{Zn}$ & 3 & 58.70 & 162.00 & 98.00 & 88.67 & 55.90 & 0.57 & 62 \\
\hline
\end{tabular}


Table 7. Cont.

\begin{tabular}{|c|c|c|c|c|c|c|c|c|}
\hline Substance & $\mathbf{N}$ & $\underset{(\mathrm{mg} / \mathrm{kg})}{\operatorname{Minimum}}$ & $\underset{(\mathrm{mg} / \mathrm{kg})}{\operatorname{Maximum}}$ & $\begin{array}{l}\text { Mean } \\
(\mathrm{mg} / \mathrm{kg})\end{array}$ & $\begin{array}{c}\mathrm{GM} \\
(\mathrm{mg} / \mathrm{kg})\end{array}$ & SD & $\mathrm{CV}$ & $\begin{array}{l}\text { Worldwide Background Mean } \\
\text { Content (mg/kg) [68] }\end{array}$ \\
\hline \multicolumn{9}{|c|}{ PAHs and phenol } \\
\hline ACTE & 6 & 0.0125 & 0.0430 & 0.0176 & 0.0154 & 0.0125 & 0.71 & - \\
\hline ACTY & 6 & 0.0125 & 0.0460 & 0.0181 & 0.0155 & 0.0137 & 0.76 & - \\
\hline ANT & 6 & 0.0125 & 0.1970 & 0.0599 & 0.0405 & 0.0683 & 1.14 & - \\
\hline $\mathrm{B}(\mathrm{a}) \mathrm{A}$ & 6 & 0.0680 & 0.7230 & 0.2777 & 0.2182 & 0.2281 & 0.82 & - \\
\hline $\mathrm{B}(\mathrm{a}) \mathrm{P}$ & 6 & 0.0820 & 1.3400 & 0.4007 & 0.2700 & 0.4655 & 1.16 & - \\
\hline $\mathrm{B}(\mathrm{b}) \mathrm{F}$ & 6 & 0.1360 & 1.8700 & 0.5632 & 0.3870 & 0.6471 & 1.15 & - \\
\hline $\mathrm{B}(\mathrm{g}, \mathrm{h}, \mathrm{i}) \mathrm{P}$ & 6 & 0.0610 & 0.9660 & 0.3003 & 0.2067 & 0.3316 & 1.10 & - \\
\hline $\mathrm{B}(\mathrm{k}) \mathrm{F}$ & 6 & 0.0380 & 0.6070 & 0.1940 & 0.1355 & 0.2064 & 1.06 & - \\
\hline $\mathrm{CHR}$ & 6 & 0.0730 & 1.1500 & 0.3330 & 0.2191 & 0.4044 & 1.21 & - \\
\hline $\mathrm{D}(\mathrm{a}, \mathrm{h}) \mathrm{A}$ & 6 & 0.0125 & 0.0125 & 0.0125 & 0.0125 & 0.0000 & NA & - \\
\hline FEN & 6 & 0.0500 & 0.5170 & 0.1970 & 0.1526 & 0.1658 & 0.84 & - \\
\hline FLU & 6 & 0.0125 & 0.0390 & 0.0169 & 0.0151 & 0.0108 & 0.64 & - \\
\hline FLUA & 6 & 0.1210 & 1.7960 & 0.5825 & 0.4118 & 0.6083 & 1.04 & - \\
\hline $\mathrm{I}(1,2,3-\mathrm{cd}) \mathrm{P}$ & 6 & 0.0720 & 1.1200 & 0.3447 & 0.2370 & 0.3854 & 1.12 & - \\
\hline NAF & 6 & 0.0125 & 0.0125 & 0.0125 & 0.0125 & 0.0000 & NA & - \\
\hline PIR & 6 & 0.1040 & 1.6400 & 0.5173 & 0.3582 & 0.5611 & 1.08 & - \\
\hline Phenol & 6 & 0.0050 & 0.0050 & 0.0050 & 0.0050 & 0.0000 & NA & - \\
\hline
\end{tabular}

NAF: naphthalene, D(a,h)A: dibenzo(a,h)anthracene, $\mathrm{B}(\mathrm{g}, \mathrm{h}, \mathrm{i}) \mathrm{P}$ : benzo $(\mathrm{g}, \mathrm{h}, \mathrm{i})$ perylene, FLU: fluorene, ANT: anthracene, B(a)P: benzo(a)pyrene, I(1,2,3-cd)P: indeno ((1,2,3-cd) pyrene, FEN: phenanthrene, CHR: chrysene, $\mathrm{B}(\mathrm{b}) \mathrm{F}$ : benzo(b)fluoranthene, ACTE: acenaphthene, FLUA: fluoranthene, $\mathrm{B}(\mathrm{a}) \mathrm{A}$ : benzo(a)anthracene, $\mathrm{B}(\mathrm{k}) \mathrm{F}$ : benzo(k)fluoranthene, ACTY: acenaphthylene, PIR: pyrene; ND: not determined; 0.0125, 0.050, 0.005: numbers in italics mean half of the limit of quantification (LOQ) and relate to the content of the substance below LOQ.

Table 8. The sum of 16 PAHs in sectors and backyards $(\mathrm{mg} / \mathrm{kg})$.

\begin{tabular}{|c|c|c|c|c|c|c|c|c|c|c|c|c|c|c|c|c|c|c|c|c|}
\hline Sector No. & 11 & 12 & 21 & 22 & 23 & 24 & 25 & 31 & 32 & 33 & 34 & 35 & 41 & 42 & 43 & 44 & 45 & 46 & 47 & 51 \\
\hline Sum of 16 PAHs & 3.0 & 6.5 & 2.8 & 2.8 & 2.3 & 5.8 & 6.3 & 4.8 & 75.5 & 7.3 & 23.4 & 24.7 & 0.2 & 0.2 & 1.0 & 6.1 & 3.4 & 2.5 & 7.1 & 4.3 \\
\hline Backyard No. & K02 & K11 & K26 & K30 & K31 & K33 & & & & & & & & & & & & & & \\
\hline Sum of 16 PAHs & 2.8 & 2.4 & 0.9 & 12.1 & 2.8 & 2.1 & & & & & & & & & & & & & & \\
\hline
\end{tabular}

Mean content of 16 PAHs in sectors- $9.50 \mathrm{mg} / \mathrm{kg}$; mean content of 16 PAHs in backyards $-3.85 \mathrm{mg} / \mathrm{kg}$.

The sum of 16 PAHs' content was above the threshold value of $0.2 \mathrm{mg} / \mathrm{kg}$ in most of the sectors and all backyards. Only in two sectors (41 and 42), was the sum of 16 PAHs equal to $0.2 \mathrm{mg} / \mathrm{kg}$. The highest sum of 16 PAHs' content was found in sector 32, exceeding by 378 times the threshold value. Among the backyards, the highest sum of 16 PAHs $^{\prime}$ content was found in backyard K30, exceeding the value of $0.2 \mathrm{mg} / \mathrm{kg}$ by about 60 times. The mean content of 16 PAHs estimated for all sectors $(9.5 \mathrm{mg} / \mathrm{kg})$ was 47.5 times higher than the threshold value and several times higher than those reported for different urban areas, e.g., Beijing, China $(1.23 \mathrm{mg} / \mathrm{kg})$, [70], Bergen, Norway $(6.78 \mathrm{mg} / \mathrm{kg})$, [71] and Lisbon, Portugal (1.54 mg/kg), [10].

\subsection{Health Risk Assessment in Sampling Sectors}

The total non-cancer risks (total HIs) calculated for children and adults and the total CRs calculated for aggregate residents in all sampling sectors are shown in Table 9. More detailed results, including the HQs, $\mathrm{HI}$ and CRs estimated for the individual contaminant in each sampling sectors are shown in Tables S1-S60 (see Supplementary Material 2).

The total HIs for children vary from $\mathrm{HI}=0.001$ in sectors 41 and 42 to $\mathrm{HI}=0.35$ in sector 24. They are significantly lower than the $\mathrm{TR}_{\mathrm{N}}$ of 1 . The total HIs for adults range from $\mathrm{HI}=0.00022$ in sector 41 to $\mathrm{HI}=0.045$ in sector 32 and are obviously lower than for children in all sampling sectors. Due to hand- and object-to-mouth behaviour, young children unintentionally ingest more soil than adults, which results in higher HIs [45,48,72-74].

The total $C$ Rs vary from $C R=2.8 \times 10^{-7}$ in sectors 41 and 42 to $C R=7.2 \times 10^{-5}$ in sector 32. In no sector does the total CR exceed the $\mathrm{TR}_{\mathrm{C}}$ of $1 \times 10^{-4}$. The total CRs in the sampling sectors are illustrated in Figure 6. 
Table 9. Total hazard indices (HIs) and total cancer risks (CRs) in sectors.

\begin{tabular}{|c|c|c|c|}
\hline Sector No. & Total HI-Children & Total HI-Adults & Total CR-Aggregate Residents \\
\hline 11 & $2.0 \times 10^{-1}$ & $2.4 \times 10^{-2}$ & $1.4 \times 10^{-5}$ \\
\hline 12 & $3.2 \times 10^{-1}$ & $3.7 \times 10^{-2}$ & $2.3 \times 10^{-5}$ \\
\hline 21 & $1.4 \times 10^{-1}$ & $1.7 \times 10^{-2}$ & $1.1 \times 10^{-5}$ \\
\hline 22 & $1.9 \times 10^{-1}$ & $2.2 \times 10^{-2}$ & $1.2 \times 10^{-5}$ \\
\hline 23 & $2.3 \times 10^{-1}$ & $2.7 \times 10^{-2}$ & $1.8 \times 10^{-5}$ \\
\hline 24 & $3.5 \times 10^{-1}$ & $4.1 \times 10^{-2}$ & $2.7 \times 10^{-5}$ \\
\hline 25 & $3.2 \times 10^{-1}$ & $3.6 \times 10^{-2}$ & $2.2 \times 10^{-5}$ \\
\hline 31 & $2.9 \times 10^{-2}$ & $3.7 \times 10^{-3}$ & $5.8 \times 10^{-6}$ \\
\hline 32 & $3.2 \times 10^{-1}$ & $4.5 \times 10^{-2}$ & $7.2 \times 10^{-5}$ \\
\hline 33 & $3.8 \times 10^{-2}$ & $5.0 \times 10^{-3}$ & $9.0 \times 10^{-6}$ \\
\hline 34 & $1.4 \times 10^{-1}$ & $1.8 \times 10^{-2}$ & $3.2 \times 10^{-5}$ \\
\hline 35 & $2.0 \times 10^{-1}$ & $2.8 \times 10^{-2}$ & $4.2 \times 10^{-5}$ \\
\hline 41 & $1.0 \times 10^{-3}$ & $2.2 \times 10^{-4}$ & $2.8 \times 10^{-7}$ \\
\hline 42 & $1.0 \times 10^{-3}$ & $2.3 \times 10^{-4}$ & $2.8 \times 10^{-7}$ \\
\hline 43 & $4.2 \times 10^{-3}$ & $6.3 \times 10^{-4}$ & $9.2 \times 10^{-7}$ \\
\hline 44 & $3.5 \times 10^{-2}$ & $4.5 \times 10^{-3}$ & $7.9 \times 10^{-6}$ \\
\hline 45 & $2.0 \times 10^{-2}$ & $2.6 \times 10^{-3}$ & $4.3 \times 10^{-6}$ \\
\hline 46 & $1.3 \times 10^{-2}$ & $1.7 \times 10^{-3}$ & $2.8 \times 10^{-6}$ \\
\hline 47 & $3.8 \times 10^{-2}$ & $5.1 \times 10^{-3}$ & $8.8 \times 10^{-6}$ \\
\hline 51 & $2.1 \times 10^{-2}$ & $2.8 \times 10^{-3}$ & $4.8 \times 10^{-6}$ \\
\hline
\end{tabular}

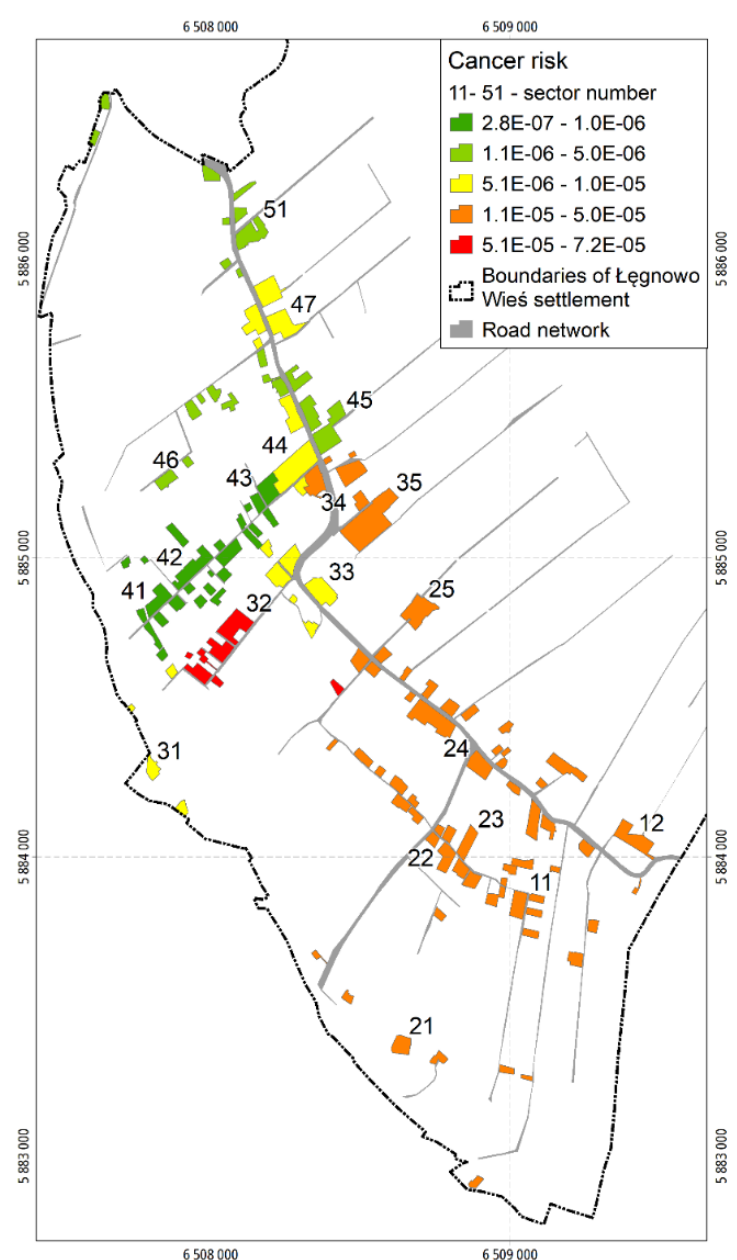

Figure 6. Map of total cancer risks in sectors.

Considering the individual carcinogens, only CRs calculated for benzo(a)pyrene and chromium (VI) are insignificantly higher than $1 \times 10^{-5}$ and relate to sectors 32, 34, 35 (Tables S27, S33 and S36) and sectors 23 and 24 (Tables S15 and S18), respectively (see Supplementary Material 2). 
As for chromium (VI), the CR risk is subject to uncertainty because it was calculated assuming that the content of chromium (VI) in soil is $1 / 7$ of the total chromium content [75], which is not necessarily reflected in local conditions.

\subsection{Health Risk Assessment in Backyards}

The total non-cancer risks (total HIs) calculated for children and adults and the total CRs calculated for aggregate residents in all analysed backyards are shown in Table 10. More detailed results, including the HQs, $\mathrm{HI}$ and CRs estimated for the individual contaminant in each backyard are shown in Tables S61-S78 (see Supplementary Material 2).

Table 10. Total hazard indices (HIs) and total cancer risks (CRs) in backyards.

\begin{tabular}{cccc}
\hline Backyard (Well No.) & Sector No. & Total HI-Children & Total HI-Adults \\
\hline K02 & 51 & $1.6 \times 10^{-2}$ & $2.0 \times 10^{-3}$ \\
K11 & 44 & $1.6 \times 10^{-2}$ & $2.0 \times 10^{-3}$ \\
K26 & 46 & $5.1 \times 10^{-3}$ & $7.1 \times 10^{-4}$ \\
K30 & 25 & $4.0 \times 10^{-1}$ & $4.6 \times 10^{-2}$ \\
K31 & 23 & $2.5 \times 10^{-1}$ & $2.8 \times 10^{-6} \times 10^{-2}$ \\
K33 & 21 & $1.9 \times 10^{-1}$ & $2.2 \times 10^{-2}$ \\
\hline
\end{tabular}

The total HIs for children vary from $\mathrm{HI}=0.0051$ (backyard $\mathrm{K} 26$ ) to $\mathrm{HI}=0.40$ (backyard 30). They are significantly lower than the $\mathrm{TR}_{\mathrm{N}}$ of 1 . The total HIs for adults vary from $\mathrm{HI}=0.00071$ (backyard K26) to $\mathrm{HI}=0.046$ (backyard K30) and are lower than for children in all analysed backyards.

The total CRs vary from $C R=1.2 \times 10^{-6}$ (backyard K26) to $C R=3.4 \times 10^{-5}$ (backyard K30). In no backyard does the total CR exceed the $\mathrm{TR}_{C}$ of $1 \times 10^{-4}$. The total CRs in the backyards are presented also in Figure 7.

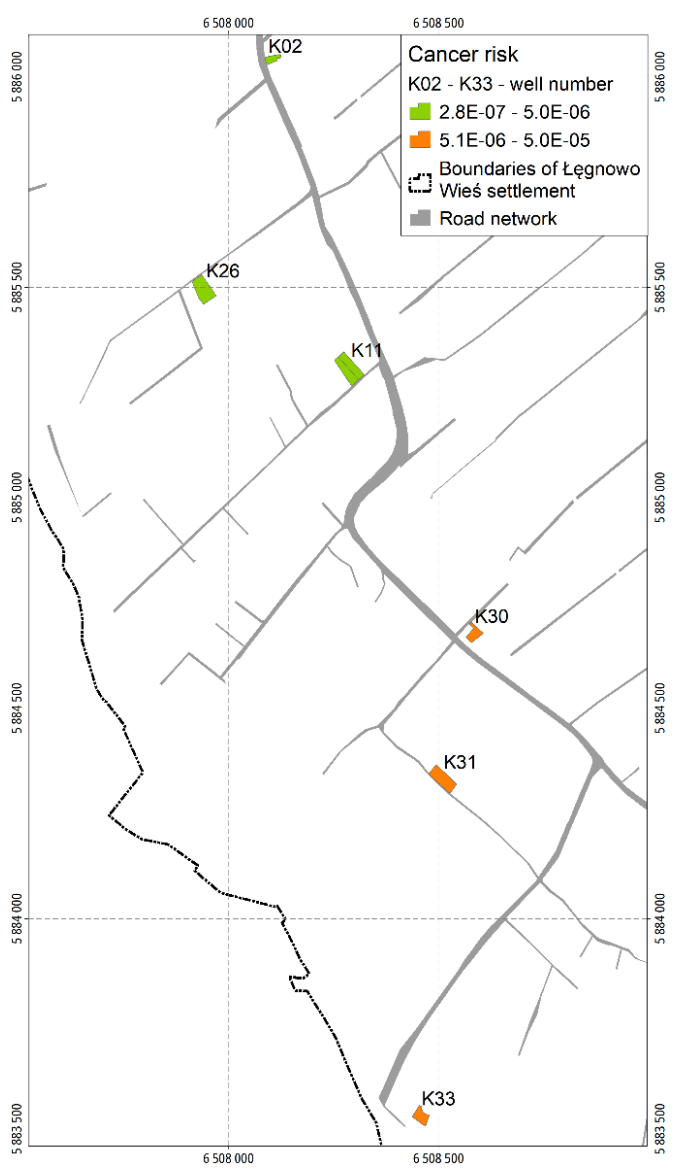

Figure 7. Map of total cancer risks in backyards. 
As in the case of the sampling sectors, only CRs calculated for benzo(a)pyrene and chromium (VI) are insignificantly higher than $1 \times 10^{-5}$ and relate to the backyard K30. Their values amount to $1.2 \times 10^{-5}$ for both benzo(a)pyrene and chromium (VI) (see Table S72 in Supplementary Material 2).

Soil ingestion is the main exposure pathway and oral HIs and oral CRs mostly contribute to the total HIs and total CRs, respectively (see Tables S1-S78). It should be noticed that direct ingestion is generally considered to be the most important pathway in human exposure to soil contaminants, constituting the basis for soil remediation $[72,76]$.

\subsection{Uncertainties of the Risk Assessment}

The presented risk estimates may be accompanied by uncertainties. They may be related to the substance selection, exposure assumptions, toxicity assessment and risk characterisation, as described below.

\section{(1) Selection of substances}

The ŁWS contaminants were selected based on the contamination sources and the most probable location of the groundwater contamination plumes delineated in 2017 [37]. However, the extent of the identified plums may change as further investigation is carried out. This would require the installation of additional piezometers, as well as the collection and application of new data on contaminant content in the groundwater. The application of updated data could improve the quality of information about the location and boundaries of the plumes and their contamination. As a consequence, it could result in the verification of the list of selected contaminants.

\section{(2) Exposure assumptions}

The site-specific exposure parameter values for the residents of the ŁWS were unavailable; therefore, the defaults suggested by Wcisło $[40,51]$ were used. These values were generally adapted from USEPA documents [47-50]; however, they can be considered as realistic estimates to be applied to calculate RME in Polish conditions when the site-specific data are unavailable or incomplete. Moreover, it should be noted that although assumptions made in the residential exposure scenario were based on the best professional judgement, they may not be accurate for specific individuals whose characteristics may vary from the conservative generic conditions.

Another uncertainty may be associated with the assumption that the residents' exposure to the site contaminants remains constant over time under the present conditions, although the actual conditions in the site are more likely to reflect an intermittent or irregular exposure situation.

\section{(3) Toxicity assessment}

The substances that are simultaneously present in the mixture, which is the case in $Ł W S$, may interact and cause different toxic effects than the individual substances separately. Potential interactions between components have been described as additive, synergistic, antagonistic and potentiating [64,77]. However, there are still many gaps in knowledge and data regarding the quantification of these interactions and the assessment of the toxicity of the chemical mixtures, despite the fact that many new methods and approaches have been recently developed [77-81]. Due to the lack of adequate knowledge, the potential interactions between the selected contaminants could not be considered in the HRA for the EWS.

Another uncertainty may be related to the use of parent organic compounds in the HRA, although their toxic derivatives may also be present in the ŁWS soil. However, it was not possible to predict which derivatives were potentially present in the soil.

Another area of uncertainty is the use of the USEPA-derived toxicity measures, i.e. cancer slope factors, reference doses and reference concentrations 50]. They are used as single point estimates that have the uncertainty associated with their derivation. On the other hand, it should be emphasised that they are derived to be conservative and provide upper bound risk estimates [82]. 


\section{(4) Risk characterisation}

The uncertainties in the risk characterisation result from the uncertainties identified in the previous steps of the risk assessment. Because of the lack of scientific knowledge about the interactions among the substances occurring in the ŁWS soil, risk additivity was applied to calculate HIs and CRs.

The uncertainties in the HRA for the $Ł W S$ residents could only be described in qualitative terms, and it was impossible to make scientifically rigorous statements about the impact of these uncertainties on the HRA results. It should be emphasised, however, that the assumptions made in the risk assessment are conservative and help prevent the underestimation of non-cancer health effects or cancer risk in the ŁWS. This protective approach is reflected in the use of conservative toxicity measures and default exposure parameter values that represent RME.

Summing up, the risk assessment findings show that both non-cancer and cancer risks are below the acceptable risk levels, i.e., total hazard index equal to 1 and total cancer risk of $1 \times 10^{-4}$, respectively. They can be considered to be protective for the majority of residents in Łegnowo-Wieś settlement.

\subsection{Site-Specific Health Risk-Based Target Levels (HRBTLs) for Soil Contaminants}

The HRBTLs developed for soil contaminants are presented in Table 11. For each HRBTL, the effect (cancer, non-cancer or mutagenic) was indicated, which was the basis for deriving these values.

Table 11. Health risk-based target levels (HRBTLs).

\begin{tabular}{|c|c|c|}
\hline Substance & \multicolumn{2}{|c|}{ HRBTL (mg/kg) } \\
\hline \multicolumn{3}{|l|}{ Metals and metalloids } \\
\hline Arsenic & 6.10 & $\mathrm{C}$ \\
\hline Barium & 11,000 & $\mathrm{~N}$ \\
\hline Chromium (III) & 37,000 & $\mathrm{~N}$ \\
\hline Chromium (VI) & 1.40 & M \\
\hline Tin & 46,000 & $\mathrm{~N}$ \\
\hline Zinc & 23,000 & $\mathrm{~N}$ \\
\hline Cobalt & 23 & $\mathrm{~N}$ \\
\hline Copper & 3000 & $\mathrm{~N}$ \\
\hline Nickel & 920 & $\mathrm{~N}$ \\
\hline Lead & 400 & {$[83,84]$} \\
\hline Mercury & 17 & $\mathrm{~N}$ \\
\hline \multicolumn{3}{|c|}{ Polycyclic aromatic hydrocarbons (PAHs) } \\
\hline Acenaphthene & 3400 & $\mathrm{~N}$ \\
\hline Anthracene & 17,000 & $\mathrm{~N}$ \\
\hline Benzo(a)anthracene & 11 & M \\
\hline Benzo(a)pyrene & 1.1 & M \\
\hline Benzo(b)fluoranthene & 11 & M \\
\hline Benzo(k)fluoranthene & 110 & M \\
\hline Chrysene & 1100 & M \\
\hline Dibenzo(a,h)anthracene & 1.1 & M \\
\hline Fluoranthene & 2300 & $\mathrm{~N}$ \\
\hline Fluorene & 2300 & $\mathrm{~N}$ \\
\hline Indeno(1,2,3-cd)pyrene & 11 & M \\
\hline Naphthalene & 18 & $\mathrm{C}$ \\
\hline Pyrene & 1700 & $\mathrm{~N}$ \\
\hline \multicolumn{3}{|l|}{ Other substances } \\
\hline Phenol & 18,000 & $\mathrm{~N}$ \\
\hline
\end{tabular}

N: non-cancer effect; C: cancer effect; M: mutagenic effect. 
The HBRLs were compared to the soil contaminant content determined in each sector and backyard (see Supplementary Material-Table S1a,b). The findings show that the content of all the analysed contaminants are lower than their HRBTLs, except for benzo(a)pyrene. B(a)P content, as the only one, was insignificantly higher than the HBRL of $1.1 \mathrm{mg} / \mathrm{kg}$ in three sectors $(32,34$ and 35$)$ and one backyard (K30), which is consistent with the HRA results.

It should be noticed, however, that the total cancer risks in all sectors and backyards do not exceed the acceptable total cancer risk of $1 \times 10^{-4}$. Taking into consideration that this risk assessment applies conservative assumptions, it can be concluded that the soil in the residential area is safe for the $€ W S$ residents.

Nevertheless, it must be remembered that the health risk was assessed taking into account only direct soil exposure pathways. It did not include other possible exposure pathways, for example, those resulting from the consumption of fruit from home gardens and local arable crops [14,15,28,85]. Fruit contamination can occur even when soil is uncontaminated if the fruit tree roots reach the contaminated groundwater. The arable crops, on the other hand, can be contaminated if they are cultivated in the area with a high level of groundwater, as is the case in ŁWS. Therefore, further research should take into account the exposure of $€ W S$ residents to potential contaminants through the consumption of locally grown food.

\section{Conclusions}

The health risk posed to the residents of the Łegnowo-Wieś settlement situated in the vicinity of the former Zachem Chemical Plant was assessed. Due to the unique site history and site contamination profile, a specific strategy for soil sampling and contaminant selection was proposed. The strategy is innovative, entirely developed by the authors. Taking into account the location and boundaries of the groundwater contamination plumes in relation to contamination sources, the strategy allowed selecting substances for risk assessment specifically for each sector of the residential area. It resulted in limiting the number of the analysed contaminants necessary to carry out the assessment. In spite of many contamination sources being identified at the site and the complexity of the contamination, the risk assessment findings show that both non-cancer and cancer risks are below their acceptable risk levels, i.e., total hazard index equal to 1 and total cancer risk of $1 \times 10^{-4}$, respectively. Taking into consideration that this risk assessment applies conservative assumptions, it can be concluded that the soil in the residential area is safe for the $Ł W S$ residents and no remedial actions are required. However, it must be pointed out that this conclusion refers only to direct soil exposure pathways, i.e., incidental ingestion, dermal contact and inhalation, which means that other potential exposure pathways cannot be neglected, e.g., consumption of fruit from home gardens and local arable crops. Therefore, further research focused on the assessment of health risk resulting from the consumption of locally grown food would be highly recommended.

Supplementary Materials: The following supporting information can be downloaded at: https: / / www.mdpi.com/article/10.3390/ijerph19052590/s1: Supplementary Materials 1: Content of analysed contaminants in surface soil (Table S1a,b); Supplementary Materials 2: Health risk assessment results (Tables S1-S78).

Author Contributions: Conceptualisation, E.W. and J.B.; data analysis, E.W. and J.B., risk calculations, E.W.; writing-original draft preparation, final version reviewing and editing, E.W.; visualisation, J.B.; supervision, E.W. Both authors have read and agreed to the published version of the manuscript.

Funding: This research was funded by the City of Bydgoszcz under the GreenerSites projectEnvironmental Rehabilitation of Brownfield Sites in Central Europe, no CE394; European Union, European Regional Development Fund, Interreg CENTRAL EU. Soil sampling according to the soil investigation strategy developed by the authors and lab analyses were conducted by the firm DEKONTA Polska. 
Acknowledgments: We would like to thank Mirosława Cyrana-Szram from the Institute for Ecology of Industrial Areas, Katowice, Poland for checking the English version of this article. We are also grateful for valuable comments on the revised version of the manuscript provided by Małgorzata Kowalska from the Department of Epidemiology of the Medical University of Silesia in Katowice.

Conflicts of Interest: The authors declare no conflict of interest.

\begin{abstract}
Abbreviations
BRDEP — Bydgoszcz Regional Directorate for Environmental Protection; CP-Chemical Plant; CRcancer risk; DNT—dinitrotoluene; EPI—epichlorohydrin; EPL—Environmental Protection Law; EU— European Union; HI-hazard index; HQ—hazard quotient; HRA—health risk assessment; HRBTLhealth risk-based target level; LOQ—-limit of quantification; ŁWS—Łegnowo-Wieś settlement; PAH— polycyclic aromatic hydrocarbon; PCE—-tetrachloroethene; PU—polyurethane; PVC-poly(vinyl chloride); RME—reasonable maximum exposure; TCE—-trichloroethene; TDA—-toluenediamine; $\mathrm{TDI}$-toluene diisocyanate; TNT - trinitrotoluene; $\mathrm{TR}_{\mathrm{C}}$ - cancer target risk; $\mathrm{TR}_{\mathrm{N}}$-non-cancer target risk; USEPA—United States Environmental Protection Agency
\end{abstract}

\title{
References
}

1. Payá Pérez, A.; Rodríguez Eugenio, N. Status of local soil contamination in Europe: Revision of the indicator "Progress in the management Contaminated Sites in Europe", EUR 29124. In Join Research Centre Technical Reports; Publications Office of the European Union: Luxembourg, 2018.

2. FAO; UNEP. Global Assessment of Soil Pollution; FAO: Rome, Italy; UNEP: Nairobi, Kenya, 2021. Available online: https: //www.fao.org/documents/card/en/c/cb4894en (accessed on 6 December 2021).

3. Yadav, I.C.; Devi, N.L.; Li, J.; Zhang, G.; Shakya, P.R. Occurrence, profile and spatial distribution of organochlorines pesticides in soil of Nepal: Implication for source apportionment and health risk assessment. Sci. Total. Environ. 2016, 573, 1598-1606. [CrossRef] [PubMed]

4. Rodríguez Eugenio, N.; McLaughlin, M.J.; Pennock, D. Soil Pollution: A Hidden Reality; Food and Agriculture Organization of the United Nations: Rome, Italy, 2018.

5. Alekseenko, V.A.; Bech, J.; Alekseenko, A.V.; Shvydkaya, N.V.; Roca, N. Environmental impact of disposal of coal mining wastes on soils and plants in Rostov Oblast, Russia. J. Geochem. Explor. 2018, 184, 261-270. [CrossRef]

6. Ma, W.; Tai, L.; Qiao, Z.; Zhong, L.; Wang, Z.; Fu, F.; Chen, G. Contamination source apportionment and health risk assessment of heavy metals in soil around municipal solid waste incinerator: A case study in North China. Sci. Total Environ. 2018, 631-632, 348-357. [CrossRef] [PubMed]

7. López-Abente, G.; Locutura-Rupérez, J.; Fernández-Navarro, P.; Martín-Méndez, I.; Bel-Lan, A.; Núñez, O. Compositional analysis of topsoil metals and its associations with cancer mortality using spatial misaligned data. Environ. Geochem. Health 2018, 40, 283-294. [CrossRef] [PubMed]

8. Brevik, E.C.; Slaughter, L.; Singh, B.M.; Steffan, J.J.; Collier, D.; Barnhart, P.; Pereira, P. Soil and Human Health: Current Status and Future Needs. Air Soil Water Res. 2020, 13, 1178622120934441. [CrossRef]

9. Cao, S.; Duan, X.; Zhao, X.; Ma, J.; Dong, T.; Huang, N.; Sun, C.; He, B.; Wei, F. Health risks from the exposure of children to As, $\mathrm{Se}, \mathrm{Pb}$ and other heavy metals near the largest coking plant in China. Sci. Total. Environ. 2014, 472, 1001-1009. [CrossRef]

10. Cachada, A.; Pato, P.; Rocha-Santos, P.; Ferreira da Silva, E.; Duarte, A.C. Levels, sources and potential human health risks of organic pollutants in urban soils. Sci. Total. Environ. 2012, 430, 184-192. [CrossRef]

11. Jorfi, S.; Atashi, Z.; Akhbarizadeh, R.; Khorasgani, Z.N.; Ahmadi, M. Distribution and health risk assessment of organochlorine pesticides in agricultural soils of the Aghili plain, Southwest Iran. Environ. Earth Sci. 2019, 78, 603. [CrossRef]

12. Li, Z.; Ma, Z.; van der Kuijp, T.J.; Yuan, Z.; Huang, L.A. Review of soil heavy metal pollution from mines in China: Pollution and health risk assessment. Sci. Total Environ. 2014, 468-469, 843-853. [CrossRef]

13. Wu, S.; Peng, S.; Zhang, X.; Wu, D.; Luo, W.; Zhang, T.; Zhou, S.; Yang, G.; Wan, H.; Wu, L.l. Levels and health risk assessments of heavy metals in urban soils in Dongguan, China. J. Geochem. Explor. 2015, 148, 71-78. [CrossRef]

14. Qureshi, A.S.; Hussain, I.; Ismail, S.; Khan, Q.M. Evaluating heavy metal accumulation and potential health risks in vegetables irrigated with treated wastewater. Chemosphere 2016, 163, 54-61. [CrossRef] [PubMed]

15. Lian, M.; Wang, J.; Sun, L.; Xu, Z.; Tang, J.; Yan, J.; Zeng, X.l. Profiles and potential health risks of heavy metals in soil and crops from the watershed of Xi River in Northeast China. Ecotoxicol. Environ. Saf. 2019, 169, 442-448. [CrossRef] [PubMed]

16. Ren, W.; Geng, Y.; Ma, Z.; Sun, L.; Xue, B.; Fujita, T. Reconsidering brownfield redevelopment strategy in China's old industrial zone: A health risk assessment of heavy metal contamination. Environ. Sci. Pollut. Res. 2015, 4, 2765-2775. [CrossRef] [PubMed]

17. Tepanosyan, G.; Sahakyan, L.; Belyaeva, O.; Asmaryan, S.; Saghatelyan, A. Continuous impact of mining activities on soil heavy metals levels and human health. Sci. Total. Environ. 2018, 639, 900-909. [CrossRef] 
18. Yang, Q.; Li, Z.; Lu, X.; Duan, Q.; Huang, L.; Bi, J. A review of soil heavy metal pollution from industrial and agricultural regions in China: Pollution and risk assessment. Sci. Total Environ. 2018, 642, 690-700. [CrossRef]

19. Alawi, M.A.; Azeez, A.L. Study of polycyclic aromatic hydrocarbons (PAHs) in soil samples from Al-Ahdab oil field in Waset Region, Iraq. Toxin Rev. 2016, 3-4, 69-76. [CrossRef]

20. Chen, Y.; Zhang, J.; Zhang, F.; Liu, X.; Zhou, M. Contamination and health risk assessment of PAHs in farmland soils of the Yinma River Basin, China. Ecotoxicol. Environ. Saf. 2018, 156, 383-390. [CrossRef]

21. Gereslassie, T.; Workineh, A.; Liu, X.; Yan, X.; Wang, J. Occurrence and Ecological and Human Health Risk Assessment of Polycyclic Aromatic Hydrocarbons in Soils from Wuhan, Central China. Int. J. Environ. Res. Public Health 2018, $12,2751$. [CrossRef]

22. Istrate, I.A.; Cocârță, D.M.; Wu, Z.; Stoian, M.A. Minimizing the Health Risks from Hydrocarbon Contaminated Soils by Using Electric Field-Based Treatment for Soil Remediation. Sustainability 2018, 10, 253. [CrossRef]

23. Wang, D.; Ma, J.; Li, H.; Zhang, X. Concentration and Potential Ecological Risk of PAHs in Different Layers of Soil in the Petroleum-Contaminated Areas of the Loess Plateau, China. Int. J. Environ. Res. Public Health 2018, 15, 1785. [CrossRef]

24. Swati; Ghosh, P.; Thakur, I.S. An integrated approach to study the risk from landfill soil of Delhi: Chemical analyses, in vitro assays and human risk assessment. Ecotoxicol. Environ. Saf. 2017, 143, 120-128. [CrossRef]

25. Zou, Y.; Liu, J.; Liu, X.; Jia, J. Health risk assessment of polycyclic aromatic hydrocarbons (PAHs) in the soil around thermal power plants in southwest China. J. Environ. Sci. Health Part A 2021, 56, 786-796. [CrossRef] [PubMed]

26. Bowers, R.L.; Smith, J.W.N. Constituents of potential concern for human health risk assessment of petroleum fuel releases. Q. J. Eng. Geol. Hydrogeol. 2014, 47, 363-372. [CrossRef]

27. Sam, K.; Coulon, F.; Prpich, G. A multi-attribute methodology for the prioritisation of oil contaminated sites in the Niger Delta Sci. Total Environ. 2017, 579, 1323-1332. [CrossRef] [PubMed]

28. Kahn, N.; Yaqub, G.; Hafeez, T.; Tariq, M. Assessment of Health Risk due to Pesticide Residues in Fruits, Vegetables, Soil, and Wate. J. Chem. 2020, 2020, 5497952 . [CrossRef]

29. Sailaukhanuly, Y.; Carlsen, L.; Tulegenov, A.; Nurzhanova, A.; Kenessov, B.; Kamysbayev, D.L. Distribution and risk assessment of selected organochlorine pesticides in Kyzyl Kairat village from Kazakhstan. Environ. Monit. Assess. 2016, 188, 358. [CrossRef]

30. Malina, G.; Krupanek, J.; Sievers, J.; Grossmann, J.; Meer, J.; Rijnaarts, H.H.M. Integrated management strategy for complex groundwater contamination at a megasite scale. In Soil and Water Pollution Monitoring, Protection and Remediation; NATO Science Series; Twardowska, I., Allen, H.E., Häggblom, M.M., Stefaniak, S., Eds.; Springer: Dordrecht, The Netherlands, 2006; Volume 69, pp. 567-577.

31. AMIIGA Project: Integrated Approach to Management of Groundwater Quality in Functional Urban Areas, 2019. EU Interreg CENTRAL EUROPE Programme 2016-2019. Available online: https:/ /www.interreg-central.eu/Content.Node/AMIIGA.html (accessed on 5 October 2021).

32. GreenerSites. Strategic Action Plan in Functional Urban Area Bydgoszcz in the Field of Greenersites Pilot Project Activities in the Brownfield Area: The Former Chemical Plants "Zachem". Deliverable D.T4.2.1 Interreg Europe. GreenerSites (Environmental Rehabilitation of Brownfield Sites in Central Europe). Bydgoszcz, Poland. 2019. Available online: https://www.interreg-central. eu/Content.Node/ReSites/CE394-GreenerSites-D.T.4.1.3-bydgoszcz.pdf (accessed on 20 August 2019).

33. SITPChem. Zarys historii ZACHEMU. In Historia Polskiego Przemystu Chemicznego w Latach 1980-2010; Karty z Historii Polskiego Przemysłu Chemicznego; Kijeński, J.A., Czumak-Bieniecka, A., Legocki, J., Lubiewa-Wielżyński, W., Kropiwnicki, J., Kubica, S., Kurant, B., Majchrzak, J., Nowacki, J., Orłowski, L., et al., Eds.; Stowarzyszenie Inżynierów i Techników Przemysłu Chemicznego (SITPChem): Warsaw, Poland, 2012. (In Polish)

34. Exploseum DAG Fabrik Bromberg, Leon Wyczółkowski District Museum, Bydgoszcz. Exploseum-History. Available online: http:/ / www.exploseum.pl/ (accessed on 12 April 2021).

35. UM Bydgoszcz. Historia Zakładów. 2019. Available online: https://www.bydgoszcz.pl/rozwoj-i-srodowisko/zachem/ informacje-szczegolowe/historia-zachemu/ (accessed on 18 April 2021). (In Polish)

36. Czop, M.; Pietrucin, D. Comprehensive Assessment of Ground-Water Environment in the Former Zachem Chemical Plant in Bydgoszcz; AGH University of Science and Technology: Cracow, Poland, 2016. Available online: https://www.dropbox.com/sh/ pbiwxgwc33h2dqt/AADExl_7cPs41BGJca7i_St6a/Opracowania\%20og\%C3\%B3lnodost\%C4\%99pne?dl=0\&preview=Zachem_ KomplOprac_RDOS_2016.pdf\&subfolder_nav_tracking=1 (accessed on 27 September 2019). (In Polish)

37. Czop, M.; Kret, E.; Pierri, D.; Knap, W. Synthesis of the WODA+ Research Project Entitled Assessment of the Scale of Surface Water and Shallow Groundwater Contamination in the Łegnowo and Platnowo Settlements, in the Zone of an Adverse Impact of the Former Zachem Chemical Plant; AGH University of Science and Technology: Cracow, Poland, 2018. Available online: https: //www.dropbox.com/sh/pbiwxgwc33h2dqt/AADExl_7cPs41BGJca7i_St6a/Opracowania\%20og\%C3\%B3lnodost\%C4\%99pne? dl=0\&preview=AGH_Raport_WODA\%2B_2018_druk.pdf\&subfolder_nav_tracking=1 (accessed on 27 September 2019). (In Polish)

38. Kudłacik, J.; Śliwka, R.; Wyszowska, I.; Otrębski, A.; Urbaniak, M.; Michalak, J. Report on Inventory Work of Private Wells and Piezometers Located in the Settlement of Łegnowo and in the Former Chemical Plant "Zachem" in Bydgoszcz, Groundwater Sampling and Results of Investigations Carried Out to Assess the Environmental Conditions. Greenersites Pilot Project Activities. Interreg CENTRAL EUROPE GreenerSites Project. Arcadis Company, Warsaw. 2018. Available online: https://www.bydgoszcz. pl/fileadmin/multimedia/rozwoj/Projekty_Unijne/GreenerSites/14.05.2019/Monitoring/Raport_z_inwentaryzacji.pdf (accessed on 16 August 2020). (In Polish) 
39. Regulation of the Minister of the Environment Dated 1 September 2016 on the Method of Conducting the Assessment of Land Surface Contamination (Journal of Laws 2016, Item 1395). Available online: http:/ /isap.sejm.gov.pl/isap.nsf/download.xsp/ WDU20160001395/O/D20161395.pdf (accessed on 12 May 2021). (In Polish)

40. Wcisło, E. Health risk assessment in contaminated site management. In Integrated Environmental Management of Land and Soil in European Urban Areas; Starzewska-Sikorska, A., Ed.; Instytut Podstaw Inżynierii Środowiska Polskiej Akademii Nauk: Zabrze, Poland, 2021.

41. Wcisło, E.; Rzychoń, M. Informatyczne narzędzie analizy ryzyka zdrowotnego wspomagające zarządzanie terenami zdegradowanymi chemicznie-HRA2 (Health risk analysis information technology tool for supporting contaminated land managementHRA2). In Innowacyjne Rozwiązania Rewitalizacji Terenów Zdegradowanych; Skowronek, J., Ed.; Institute for Ecology of Industrial Areas (IETU): Katowice, Poland; Research and Supervisory Center of Underground Mining (CBiDGP): Katowice, Poland, 2016; Volume 8, pp. 293-306. (In Polish)

42. USEPA. Risk Assessment Guidance for Superfund, Vol. I. Human Health Evaluation Manual. Part A. Interim Final. EPA/540/1-89/002 Office of Emergency and Remedial Response: Washington, DC, USA, 1989.

43. USEPA. Risk Assessment Guidance for Superfund, Vol. I. Human Health Evaluation Manual. Part B. Development of Risk-Based Preliminary Remediation Goals. Interim. EPA/540R-92/003; Office of Emergency and Remedial Response: Washington, DC, USA, 1991.

44. USEPA. Role of the Baseline Risk Assessment in Superfund Remedy Selection Decisions. OSWER Directive 9355.0-30; Office of Solid Waste and Emergency Response: Washington, DC, USA, 1991.

45. USEPA. Soil Screening Guidance: Technical Background Document. EPA/540/R-95/128; Office of Emergency and Remedial Response: Washington, DC, USA, 1996.

46. USEPA. Soil Screening Guidance: User's Guide. EPA/540/R-96/018; Office of Emergency and Remedial Response: Washington, DC, USA, 1996.

47. USEPA. Risk Assessment Guidance for Superfund. Vol. I. Human Health Evaluation Manual. Part D. Standardized Planning, Reporting, and Review of Superfund Risk Assessment. Final. Publication 9285.7-47; Office of Emergency and Remedial Response: Washington, DC, USA, 2001.

48. USEPA. Supplemental Guidance for Developing Soil Screening Levels for Superfund Sites. OSWER 9355.4-24; Office of Solid Waste and Emergency Response: Washington, DC, USA, 2002.

49. USEPA. Risk Assessment Guidance for Superfund. Vol. I. Human Health Evaluation Manual. Part E. Supplemental Guidance for Dermal Risk Assessment. Final. EPA/540/R/99/005. OSWER 9285.7-02EP; Office of Superfund Remediation and Technology Innovation: Washington, DC, USA, 2004.

50. USEPA. Regional Screening Levels (RSLs), User's Guide. 2021. Available online: https://www.epa.gov/risk/regional-screeninglevels-rsls-users-guide (accessed on 12 April 2021).

51. Wcisło, E. Human Health Risk Assessment in the Remediation Process of Contaminated Sites-Role and Procedures; Wydawnictwo Ekonomia i Środowisko: Białystok, Poland, 2009. (In Polish)

52. Adimalla, F. Heavy metals pollution assessment and its associated human health risk evaluation of urban soils from Indian cities: A review. Environ. Geochem. Health 2020, 42, 173-190. [CrossRef]

53. Liang, Y.; Yi, X.; Dang, Z.; Wang, Q.; Luo, H.; Tang, J. Heavy Metal Contamination and Health Risk Assessment in the Vicinity of a Tailing Pond in Guangdong, China. Int. J. Environ. Res. Public Health 2017, 14, 1557. [CrossRef]

54. Miao, F.; Zhang, Y.; Li, Y.; Lin, Q.A. Synthetic health risk assessment based on geochemical equilibrium simulation and grid spatial interpolation for zinc (II) species. J. Environ. Manag. 2022, 304, 114207. [CrossRef]

55. Müller, L.; Ramires, P.F.; dos Santos, M.; Coronas, M.V.; Lima, W.; Dias, D.; Muccillo-Baisch, A.L.; Baisch, P.R.M.; da Silva Júnior F.M.R.L. Human health risk assessment of arsenic in a region influenced by a large coal-fired power plant. Int. J. Environ. Sci. Technol. 2022, 19, 281-288. [CrossRef]

56. Wcislo, E.; Dlugosz, J.; Korcz, M. A Human Health Risk Assessment Software for Facilitating Management of Urban Contaminated Sites: A Case Study: The Massa Site, Tuscany, Italy. Hum. Ecol. Risk Assess. 2005, 5, 1005-1024. [CrossRef]

57. Wcisło, E.; Bronder, J.; Bubak, A.; Rodríguez-Valdés, E.; Gallego, J.R. Human health risk assessment in restoring safe and productive use of abandoned contaminated sites. Environ. Int. 2016, 94, 436-448. [CrossRef]

58. Act of 27 April 2001 on Environmental Protection Law (Journal of Laws 2017, Item 519 as Amended). Available online: http:/ /isap.sejm.gov.pl/isap.nsf/download.xsp/WDU20170000519/T/D20170519L.pdf (accessed on 12 May 2021). (In Polish)

59. USEPA. Supplemental Guidance for Assessing Susceptibility from Early-Life Exposure to Carcinogens. EPA/630/R-03/003F; Risk Assessment Forum: Washington, DC, USA, 2005.

60. USEPA. Assessing Dermal Exposure from Soil. Region 3 Technical Guidance Manual, Risk Assessment. 2020. Available online: https:/ / www.epa.gov/risk/assessing-dermal-exposure-soil (accessed on 25 June 2021).

61. Chen, H.; Teng, Y.; Lu, S.; Wang, Y.; Wu, J.; Wang, J. Source apportionment and health risk assessment of trace metals in surface soils of Beijing metropolitan, China. Chemosphere 2016, 144, 1002-1011. [CrossRef] [PubMed]

62. Xiao, Y.; Guo, M.; Li, X.; Luo, X.; Pan, R.; Ouyang, T. Spatial distribution, pollution, and health risk assessment of heavy metal in agricultural surface soil for the Guangzhou-Foshan urban zone, South China. PLoS ONE 2020, 10, e0239563. [CrossRef]

63. CalEPA. Preliminary Endangerment Assessment Guidance Manual (January 1994. Revised October 2015). State of California, Environmental Protection Agency, Department of Toxic Substances Control, USA. 2015. Available online: https://www. gsweventcenter.com/Appeal_Response_References/2015_10_CalEPA.pdf (accessed on 14 October 2021). 
64. ITRC. Decision Making at Contaminated. Sites: Issues and Options in Human Health Risk Assessment. RISK-3; Interstate Technology \& Regulatory Council (ITRC), Risk Assessment Team: Washington, DC, USA, 2015. Available online: https://itrcweb.org/teams/ training/risk-assessment (accessed on 16 May 2021).

65. NAP. Risk Assessment and Uncertainty. In Environmental Decisions in the Face of Uncertainty; The National Academies Press: Washington, DC, USA, 2013; pp. 47-72.

66. USEPA. Probabilistic Risk Assessment to Inform Decision Making: Frequently Asked Questions. EPA/100/R-14/003; Office of the Science Advisor, Risk Assessment Forum, Probabilistic Risk Analysis Technical Panel: Washington, DC, USA, 2014.

67. Wcisło, E.; Korcz, M.; Długosz, J.; Demetriades, A. Risk-based Approach to Contaminated Land and Groundwater Assessment: Two Case Studies. In Clean Soil and Safe Water; NATO Science for Peace and Security Series-C: Environmental Security; Quercia, F., Vidojević, D., Eds.; Springer: Dordrecht, The Netherland, 2012; pp. 51-64.

68. Kabata-Pendias, A.; Mukherjee, A.B. Trace Elements from Soil to Humans; Springer: Berlin/Heidelberg, Germany, 2007.

69. Maliszewska-Kordybach, B. Polycyclic aromatic hydrocarbons in agricultural soils in Poland: Preliminary proposals for criteria to evaluate the level of soil contamination. Appl. Geochem. 1996, 11, 121-127. [CrossRef]

70. Peng, C.; Chen, W.; Liao, X.; Wang, M.; Ouyang, Z.; Jiao, W.; Bai, Y. Polycyclic aromatic hydrocarbons in urban soils of Beijing: Status, sources, distribution and potential risk. Environ. Pollut. 2011, 159, 802-808. [CrossRef] [PubMed]

71. Haugland, T.; Ottesen, R.T.; Volden, T. Lead and polycyclic aromatic hydrocarbons (PAHs) in surface soil from day care centers in the city of Bergen, Norway. Environ. Pollut. 2008, 153, 266-272. [CrossRef]

72. Moya, J.; Phillips, L.A. Review of soil and dust ingestion studies for children. J. Expo. Sci. Environ. Epidemiol. 2014, 24, 545-554. [CrossRef]

73. Lin, C.; Wang, B.; Cui, X.; Xu, D.; Cheng, H.; Wang, Q.; Ma, J.; Chai, T.; Duan, X.; Liu, X. Estimates of Soil Ingestion in a Population of Chinese Children. Environ. Health Perspect. 2017, 125, 077002. [CrossRef]

74. USEPA. Exposure Factors Handbook: 2011 Edition (Final Report). EPA/600/R-09/052F; National Center for Environmental Assessment, Office of Research and Development, US Environmental Protection Agency: Washington, DC, USA, 2011.

75. USEPA. Regional Screening Levels, Frequent Questions, November 2021. Available online: https://www.epa.gov/risk/regionalscreening-levels-frequent-questions (accessed on 30 November 2021).

76. European Commission. Science for Environment Policy In-Depth Report: Soil Contamination: Impacts on Human Health; Communication Unit, University of the West of England: Bristol, UK, 2013.

77. Hayes, A.W.; Li, R.; Hoeng, J.; Iskandar, A.; Peistch, M.C.; Dourson, M.L. New approaches to risk assessment of chemical mixtures. Toxicol. Res. Appl. 2019, 3, 2397847318820768. [CrossRef]

78. Bopp, S.; Berggren, E.; Kienzler, A.; van der Linden, S.; Worth, A. Scientific methodologies for the combined effects of chemicalsA survey and literature review. In JRC Technical Reports; EUR 27471 EN; European Union: Maastricht, The Netherlands, 2015. [CrossRef]

79. Bopp, S.K.; Barouki, R.; Brack, W.; Costa, S.D.; Dorne, J.-L.C.M.; Drakvik, P.E.; Faust, M.; Karjalainen, T.K.; Kephalopoulos, S.; van Klaveren, J.; et al. Current EU research activities on combined exposure to multiple chemicals. Environ. Int. 2018, 120, 544-562. [CrossRef] [PubMed]

80. Bopp, S.K.; Kienzler, A.; Richarz, A.-N.; van der Linden, S.C.; Paini, A.; Parissis, N.; Worth, A.P. Regulatory assessment and risk management of chemical mixtures: Challenges and ways forward. Crit. Rev. Toxicol. 2019, 49, 174-189. [CrossRef] [PubMed]

81. Drakvik, E.; Altenburger, R.; Aoki, Y.; Backhaus, T.; Bahadori, T.; Barouki, R.; Brack, W.; Cronin, M.T.D.; Demeneix, B.; Bennekou, S.H.; et al. Statement on advancing the assessment of chemical mixtures and their risks for human health and the environment. Environ. Int. 2020, 134, 105267. [CrossRef] [PubMed]

82. USEPA. Risk Characterization Handbook. EPA 100-B-00-002; Office of Science Policy, Office of Research and Development: Washington, DC, USA, 2000.

83. USEPA. Memorandum: OSWER Directive: Revised Interim Soil Lead Guidance for CERCLA Sites and RCRA Corrective Action Facilities. EPA OSWER Directive 9355.4-12; Office of Emergency and Remedial Response: Washington, DC, USA, 1994.

84. US EPA. Memorandum: OSWER Directive: Clarification to the 1994 Revised Interim Soil Lead (Pb) Guidance for CERCLA Sites and RCRA Corrective Action Facilities. EPA/540/F-98/030. OSWER Directive \#9200.4-27P; Office of Solid Waste and Emergency Response: Washington, DC, USA, 1998.

85. Trapp, S.; Legind, C.N. Uptake of Organic Contaminants from Soil into Vegetables and Fruits. In Dealing with Contaminated Sites. From Theory towards Practical Application, 1st ed.; Swartjes, F., Ed.; Springer: Dordrecht, The Netherlands, 2011; Volume 1, pp. 369-408. 